\title{
Quantification of acid loads and delineation of hydrochemical facies at a phreatic mine spoil aquifer
}

\author{
Mitchell A. McAdoo \\ West Virginia University
}

Follow this and additional works at: https://researchrepository.wvu.edu/etd

\section{Recommended Citation}

McAdoo, Mitchell A., "Quantification of acid loads and delineation of hydrochemical facies at a phreatic mine spoil aquifer" (2013). Graduate Theses, Dissertations, and Problem Reports. 234.

https://researchrepository.wvu.edu/etd/234

This Thesis is protected by copyright and/or related rights. It has been brought to you by the The Research Repository @ WVU with permission from the rights-holder(s). You are free to use this Thesis in any way that is permitted by the copyright and related rights legislation that applies to your use. For other uses you must obtain permission from the rights-holder(s) directly, unless additional rights are indicated by a Creative Commons license in the record and/ or on the work itself. This Thesis has been accepted for inclusion in WVU Graduate Theses, Dissertations, and Problem Reports collection by an authorized administrator of The Research Repository @ WVU. For more information, please contact researchrepository@mail.wvu.edu. 


\title{
QUANTIFICATION OF ACID LOADS AND DELINEATION OF HYDROCHEMICAL FACIES AT A PHREATIC MINE SPOIL AQUIFER
}

\author{
Mitchell A. McAdoo \\ Thesis submitted \\ to the Eberly College of Arts and Sciences \\ at West Virginia University
}

in partial fulfillment of the requirements for the degree of

Masters of Science In

Geology

\author{
Dr. Joseph J. Donovan, Chair \\ Dr. Kathleen Benison \\ Eberhard Werner \\ Department of Geology and Geography \\ Morgantown, West Virginia \\ 2013
}

Keywords: geochemistry, hydrogeology, coal, acid, hydrochemical facies, cubic spline Copyright 2013 Mitchell A. McAdoo 


\title{
ABSTRACT \\ QUANTIFICATION OF ACID LOADS AND DELINEATION OF HYDROCHEMICAL FACIES AT A PHREATIC MINE SPOIL AQUIFER
}

\begin{abstract}
Mitchell A. McAdoo
Acid mine drainage geochemistry and in situ alkaline injection were investigated at the DLM coal mine, Alton West Virginia. These included spatial and temporal investigations into hydrochemical controls that were initiated with reclamation efforts. Approaches included the delineation of hydrochemical facies and analysis of time series data to develop a methodology for estimating acid loads.

Results of agglomerative hierarchical clustering were mapped to demonstrate spatial variations in response to reclamation efforts over time. Spatial patterns were determined and indicate that aquifer chemistry continued to evolve during the study period. Results confirmed that injection of alkalinity into the aquifer effected acid producing and neutralizing reactions in monitoring wells down gradient from the injection site.

Low-frequency water chemistry was interpolated with natural cubic splines, resampled and multiplied by high-frequency flow to produce estimates of acid loads at high-frequency. Cross-correlation between high-frequency and low-frequency datasets showed an exponential decrease in correlation as the number of days between flow measurements increased. Result confirmed that natural cubic splines can be used for resampling hydrochemical time series data and the frequency at which flow is measured limits the accuracy of acid load estimates.
\end{abstract}




\section{Acknowledgments}

The author would like to thank committee members Dr. Kathleen Benison and Eberhard Werner for their advice and support. A special thanks goes to Dr. Joe Donovan for sharing your expertise, being patient and helping me through the process. You have made my time at West Virginia University a memorable experience.

I am grateful to all of the graduate students and investigators who have conducted research at DLM. The background and data obtained over the years have been instrumental in the completion of this research. Additionally, I would like to thank the West Virginia Department of Environmental Protection for funding and field support.

I am especially grateful to my wife, Kimberly McAdoo, for her sacrifice and continued support. Without her encouragement I would have never been able to accomplish my goals. 


\section{Table of Contents}

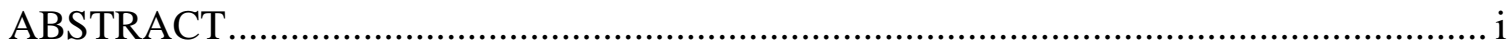

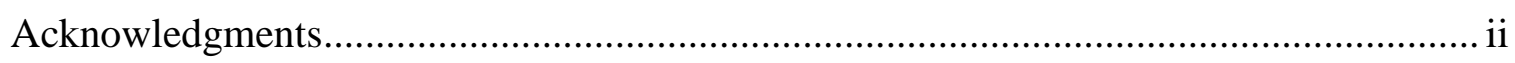

1: Introduction to the DLM Site and Surface Mine Drainage Geochemistry ..................... 1

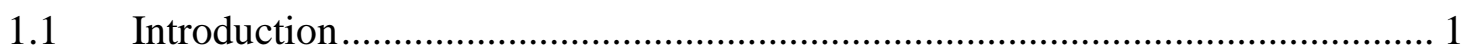

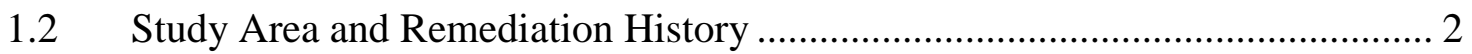

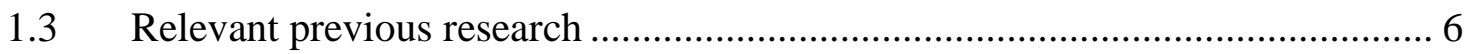

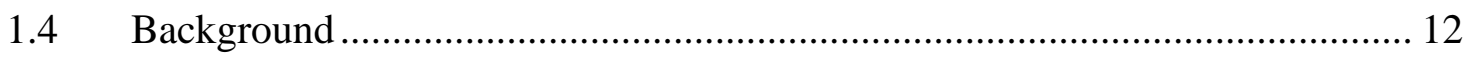

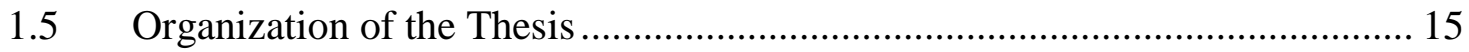

2: Delineation of Hydrochemical Facies at an Acid-Producing Mine-Spoil Aquifer....... 16

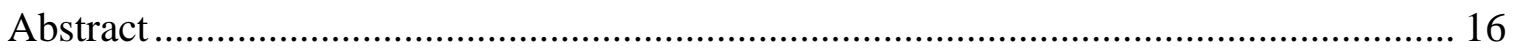

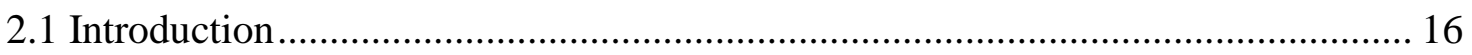

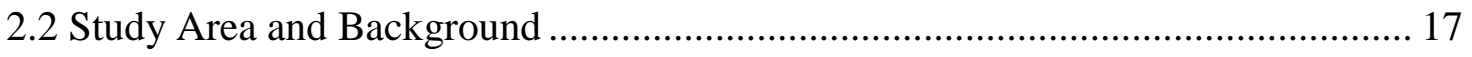

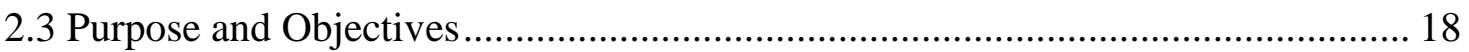

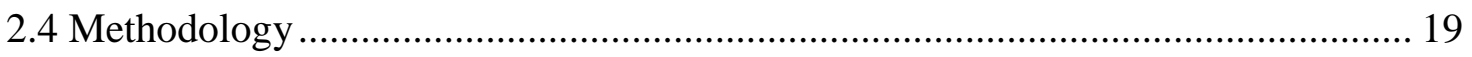

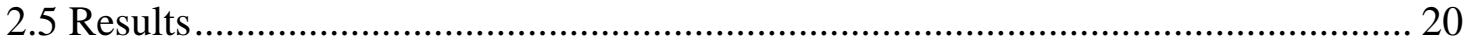

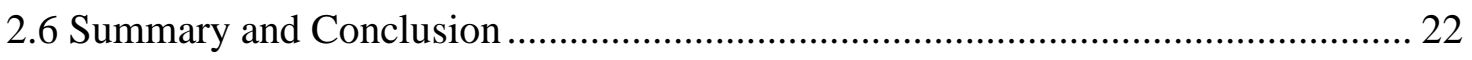

3: Quantification of Acid Loads Discharging from a Phreatic Mine-Spoil Aquifer......... 29

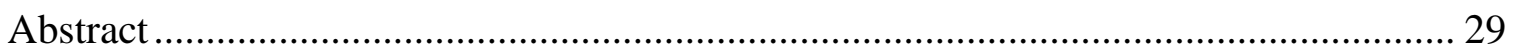

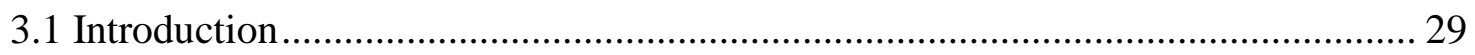

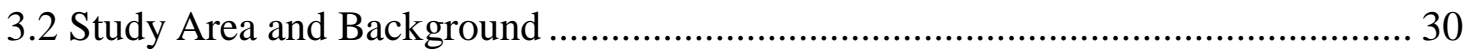

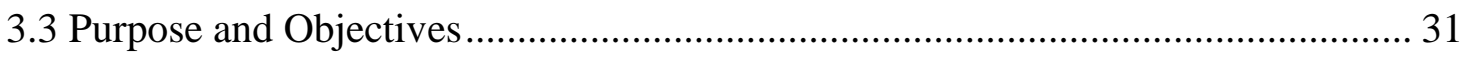

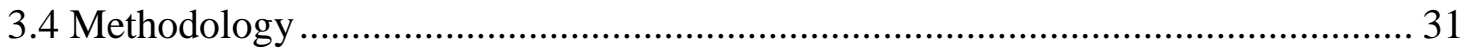


3.5 Results

3.6 Summary and Conclusion ....................................................................... 43

5: Conclusions and Future Research ................................................................... 44

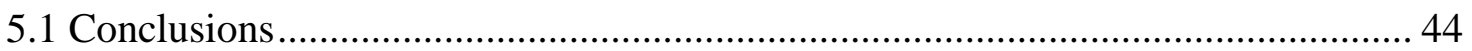

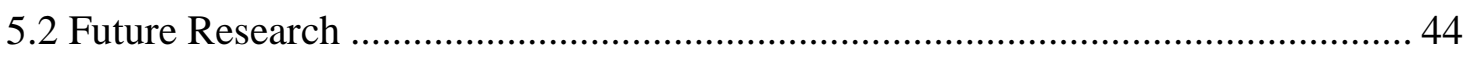

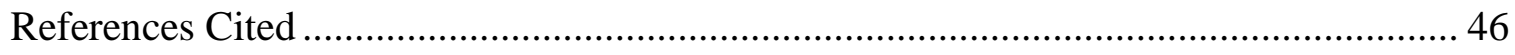

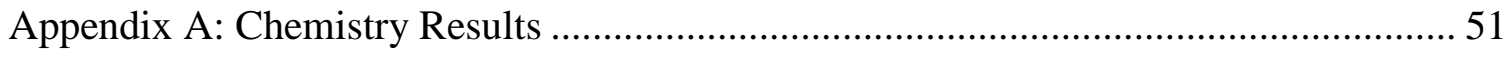

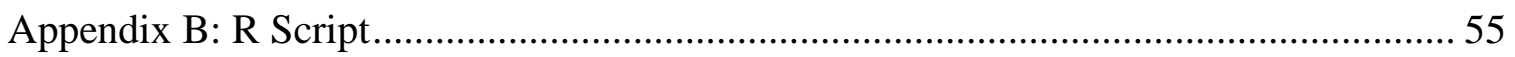

\section{Figures}

Figure 1-1: Map showing the location of the DLM site .......................................... 4

Figure 1-2: Schematic cross section of a typical mine-spoil aquifer ............................. 5

Figure 1-3: The Cutright ponds, sludge disposal pond and Plant Hollow ponds ............. 7

Figure 1-4: Map showing current well and trench locations at the DLM X bench ........... 8

Figure 1-5: Map showing spring locations of the $\mathrm{X}$ bench...................................... 9

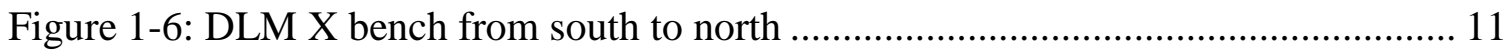

Figure 2-1: Dendrogram interpreted from cluster analysis ...................................... 23

Figure 2-2: Box plots showing chemistry of cluster centroids by group ....................... 24

Figure 2-3: Hydrochemical facies of the DLM X bench ....................................... 26

Figure 2-4: Star plot matrix with cluster group number in the lower right corner .......... 27

Figure 3-1: Interpolated acid concentrations $\left(\mathrm{mg} / \mathrm{l}\right.$ as $\left.\mathrm{CaCO}_{3}\right)$ at five flume sites.......... 35

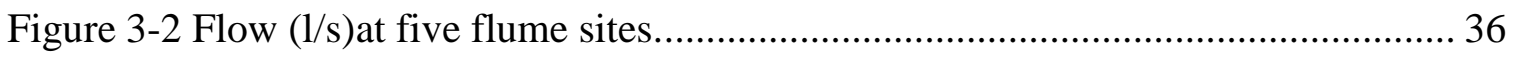

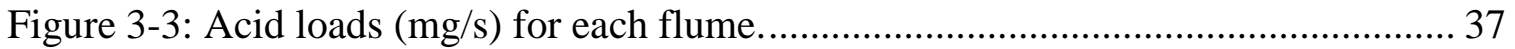


Figure 3-4: Correlation coefficients for high frequency flow.

Figure 3-5: Correlation coefficients for high frequency acid loads ............................. 40

Figure 3-6: Monthly acid loads. Grey bars indicate partial months. ............................. 41

\section{Tables}

Table 1-1: Lime slurry injection dates and amounts............................................. 10

Table 2-1: Description of cluster groups ......................................................... 25

Table 3-1: Acid discharged from the DLM X bench ................................................ 42 


\section{1: Introduction to the DLM Site and Surface Mine Drainage Geochemistry}

\subsection{Introduction}

Surface mining for coal is prevalent throughout West Virginia and is an integral part of its economy. Surface mining can have adverse effects on downstream water quality and can change the hydrologic characteristics of the mined area (Kleinmann et al, 2000). After the coal is mined, the surface topography of the mine is required to be restored to its approximate original contour. To do this, mine operators use overburden removed during mining. These fills, often referred to as mine-spoil aquifers, can become resaturated and in some cases produce acidic discharges (Donovan, 1998). Aquifers of this type pose unique hydrogeological challenges due to their extreme degree of heterogeneity and unpredictable composition.

The hydraulic gradient and groundwater flow direction of these aquifers are driven primarily by the slope of the pit floor. Hydraulic conductivity and other hydrogeologic parameters vary spatially as well as temporally due to heterogeneity of fill material, subsidence and chemical alteration within the aquifer (Hawkins, 2004). Understanding the distribution of heterogeneity and groundwater flow can help in the formulation of effective remediation projects (Callaghan et al, 2000).

Among the strategies for the control and remediation of acid mine drainage (AMD), active methods are more widespread than passive ones. Active treatment systems commonly utilize chemicals such as lime or sodium hydroxide to raise $\mathrm{pH}$ and reduce metals concentrations. Drawbacks of active remediation include continuous maintenance and the need to handle sludge produced by the precipitation of metals. Passive systems 
include the use of engineered or natural wetlands and often have high initial costs (Johnson and Hallberg, 2005).

One method to reduce sludge management problems is to employ in situ remediation techniques which introduce chemicals directly into the acid-producing material. There are two standard approaches to in situ remediation. One involves application of chemicals that reduce the amount of acid produced by inhibiting pyrite oxidation. The other involves the injection of alkalinity to precipitate metals directly within the aquifer (Werner et al, 2008). These methods can reduce treatment costs and environmental problems associated with sludge disposal. In situ remediation requires a firm understanding of the aquifers hydrogeologic framework as well as its baseline chemical composition (Canty and Everett, 2006).

\subsection{Study Area and Remediation History}

The DLM bond-forfeiture site, also known as the Alton project, is located in Upshur County, West Virginia (Fig. 1-1). It has been the focus of continued acid mine drainage remediation by the West Virginia Department of Environmental Protection (WVDEP) for the past 26 years. Coal of the Lower Kittanning seam (Pennsylvanian Age) was mined at this site from 1976 to 1983 (Sturm Environmental Services, 1986). The site is named after the DLM Coal Corporation, which forfeited its assets seized to the West Virginia Department of Energy in 1985. It is a large abandoned surface mine with three benches (X bench, $\mathrm{Y}$ bench, $\mathrm{Z}$ bench) that have been back filled with waste rock from overburden (Neumann, 2013). 
The Alton project's three mine spoil aquifers (Fig. 1-2) have undergone many years of hydrogeochemical evolution and currently discharge AMD that is characteristically formed due to pyrite oxidation and aluminosilicate mineral dissolution in mine spoil. Multiple approaches have been used to neutralize the acidity, with the most successful being active treatment techniques. The aquifers are currently treated with sodium hydroxide at their discharges, producing sludge that is settled in a series of ponds. Sludge is pumped from the settling ponds to disposal ponds (Fig. 1-3) in the central portion of the spoil piles (Donovan et al., 1997).

The spoil aquifer on which this study has focused, the X bench (Ketchum, 1998), comprises 97 acres. Multiple groundwater observation wells were drilled on the site, and trenches were excavated for injection of alkalinity (Fig. 1-4) at different times during the projects history. Water flows northwest from its recharge point until it discharges from a series of springs on the west side of the aquifer (Fig. 1-5).

In situ reclamation attempts began on the $\mathrm{X}$ bench in 1983 with the installation of three trenches filled with limestone and sodium carbonate briquettes. The trenches were installed up gradient from Springs C1and C2 but failed to yield effective acid neutralization (Caruccio et al., 1984). Following successful lime slurry experiments on the Y Bench in 1998 (Daly, 1998), injection of alkalinity began at the X bench with Trench T10 in a series of doses throughout 2000 (Neumann, 2013). Lime slurry injection resumed in 2010 with trenches T6, T7, T9 and T11 (Table 1-1). From 2000 to 2011 over 270 tons of lime was used for induced alkaline recharge into the $\mathrm{X}$ bench. 


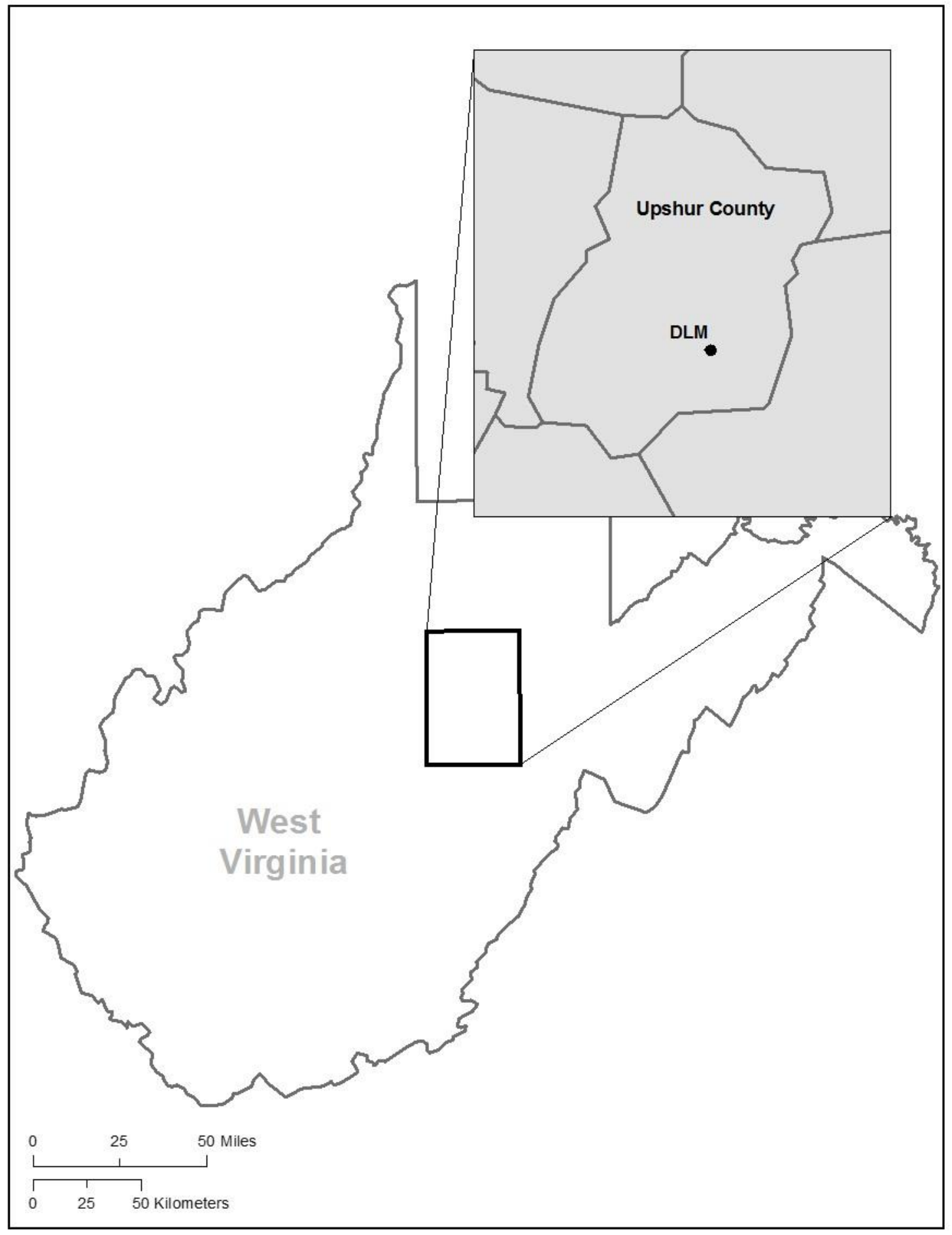

Figure 1-1: Map showing the location of the DLM site 


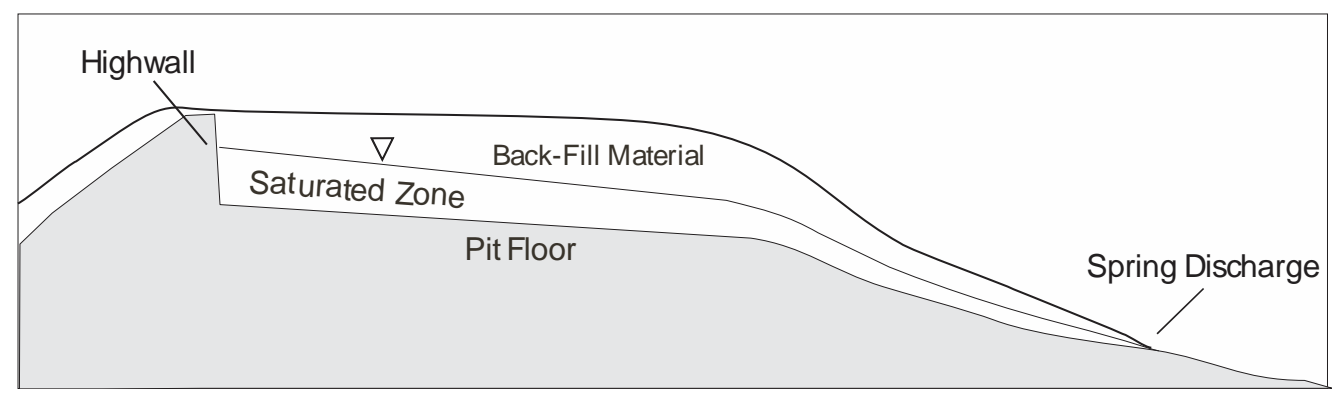

Figure 1-2: Schematic cross section of a typical mine-spoil aquifer, after Daly (1998). 
The alkaline injection process for these trenches utilized settling pond water pumped up to a mixing area near each trench where hydrated lime was dissolved to create a lime slurry (Fig. 1-6). In 2000 and early 2010 slurries were mixed by intermittent dumping from the bucket of either a bobcat or a front-end loader. Later, after December 2010, mixing was done using a continuous pneumatic jet of lime affording much more rapid mixing. Slurry flowed a short distance from here into a deep (5 m x $3 \mathrm{~m}$ x $15 \mathrm{~m})$ infiltration trench cut with a long arm bucket excavator. The lime slurry infiltrated into macropores at the bottom of these trenches and was flushed deeper into the aquifer using clear settling pond water pumped into the trench for a number of hours after mixing.

\subsection{Relevant previous research}

Numerous hydrological and geochemical studies have focused on the X Bench as well as at similar mine-spoil aquifers in the region (Sturm, 1986; Frysinger, 1995; Maher, 1996; Avery, 1997; Donovan et al., 1997; Ketchum, 1998; Ketchum et al., 2000; Neuman, 2013). In situ chemical treatment of sodium hydroxide was attempted in numerous investigations (Aljoe and Hawkins, 1993; Canty and Everett, 2006; Werner $e t$ $a l, 2008)$. Each study concluded that detailed hydrogeological and geochemical investigations should be conducted prior to injections.

Hydrogeological investigations of the X bench by Maher (1996) show heterogeneity in the aquifer in excess of three orders of magnitude. Frysinger (1995) and Avery (1997) used a preferred-flow-path conceptual model to simulate groundwater flow. 


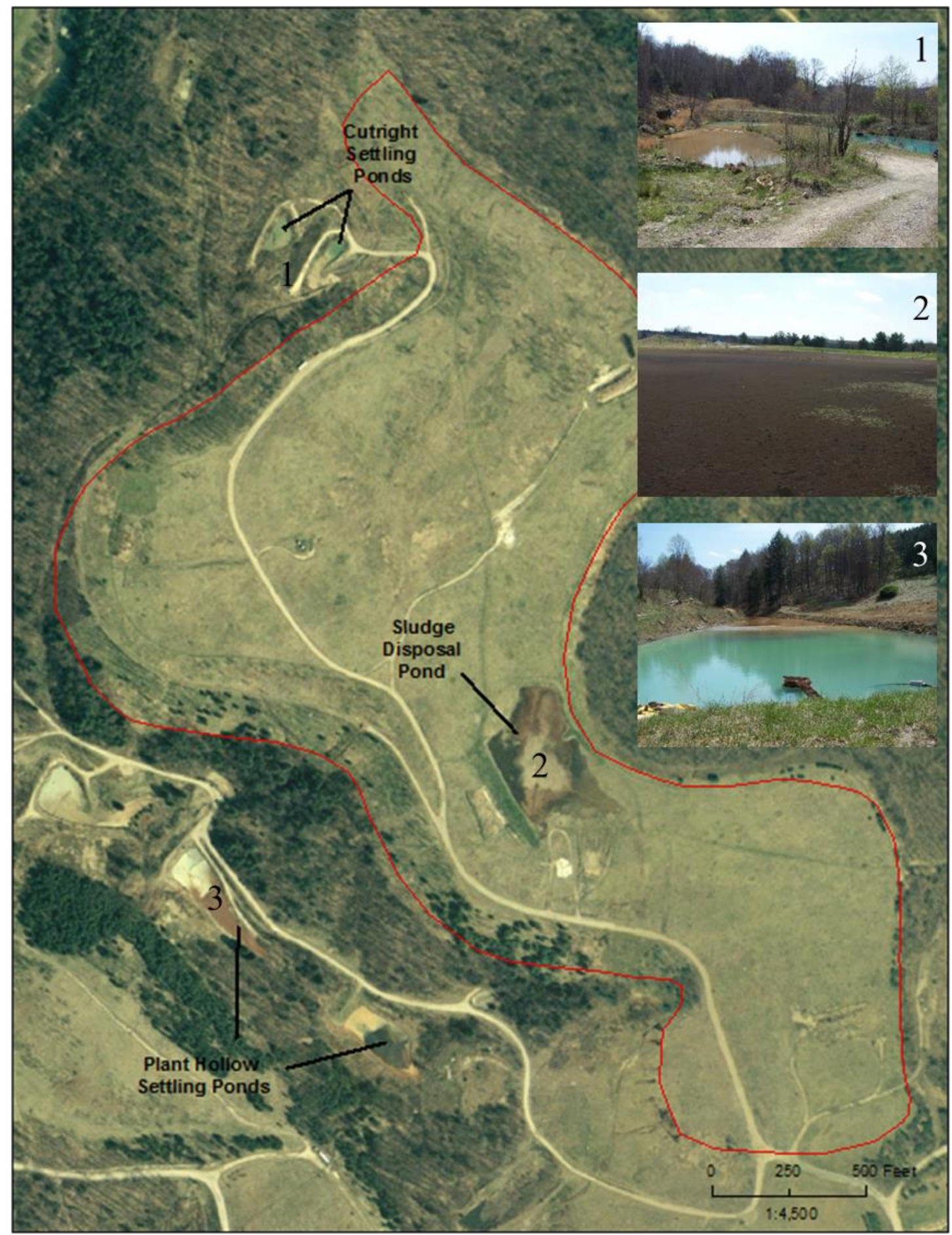

Figure 1-3: (1) The Cutright ponds, (2) sludge disposal pond and (3) Plant Hollow ponds at the DLM X bench. The red boundary represents the extent of the aquifer. 


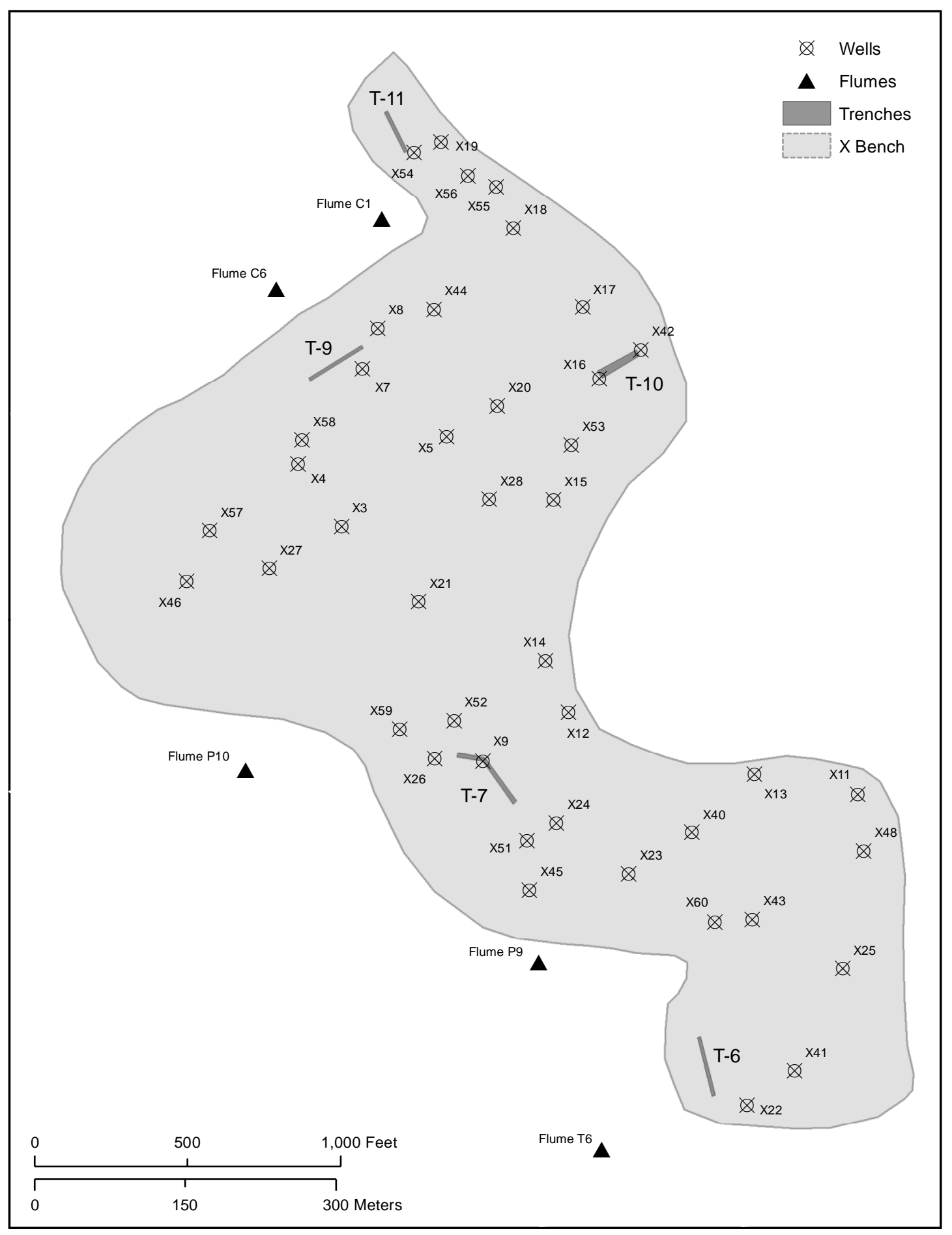

Figure 1-4: Map showing current well and trench locations at the DLM X bench 


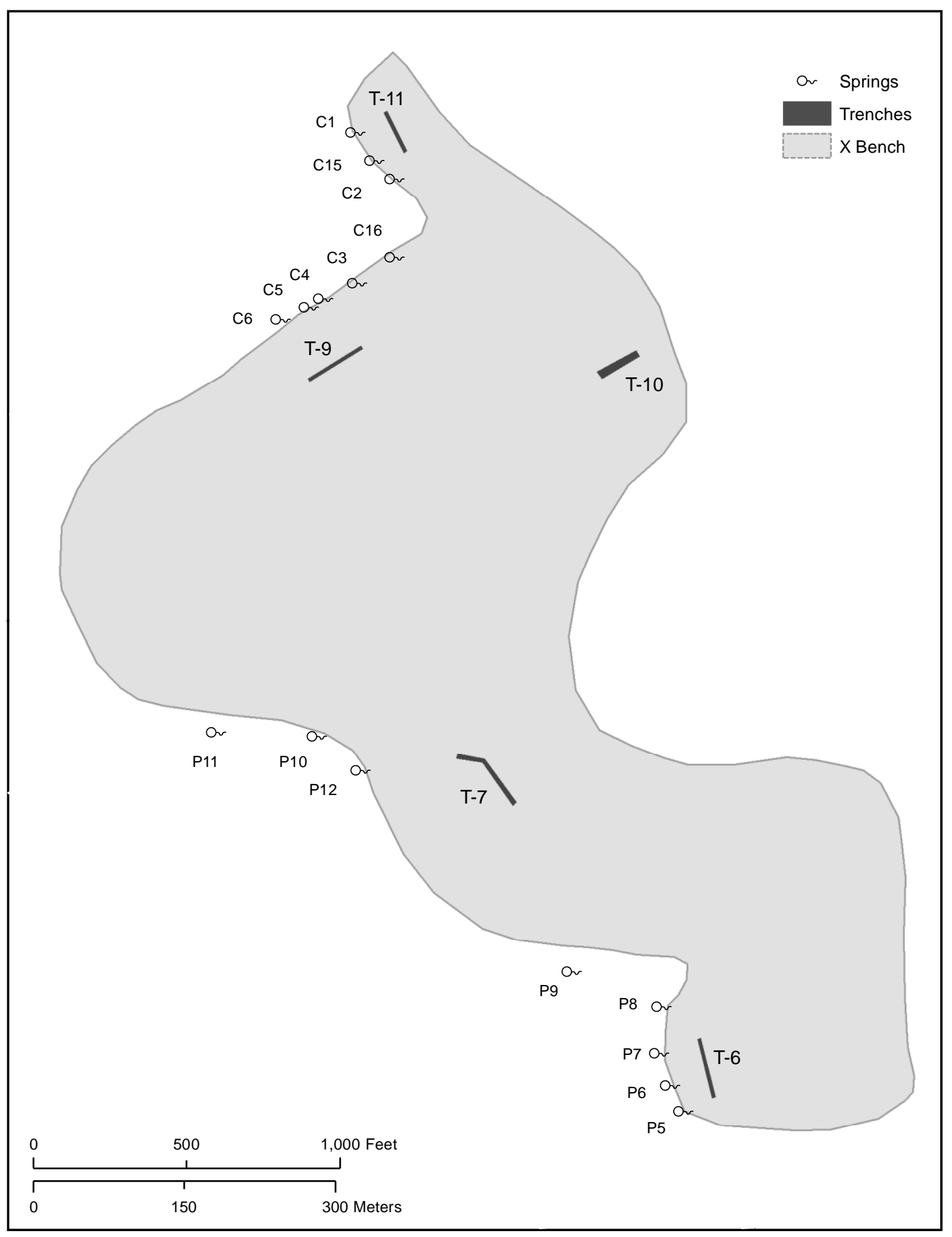

Figure 1-5: Map showing spring locations of the $\mathrm{X}$ bench and the extent of the aquifer 


\begin{tabular}{|c|c|c|}
\hline Date & Trench & $\begin{array}{c}\text { Lime } \\
\text { (tons) }\end{array}$ \\
\hline $7 / 17 / 2000$ & T10 & 6.1 \\
\hline $7 / 24 / 2000$ & T10 & 6.1 \\
\hline $8 / 7 / 2000$ & T10 & 7.6 \\
\hline $8 / 14 / 2000$ & T10 & 7.6 \\
\hline $8 / 21 / 2000$ & T10 & 6.1 \\
\hline $8 / 28 / 2000$ & T10 & 6.1 \\
\hline $8 / 30 / 2000$ & T10 & 3.0 \\
\hline $8 / 31 / 2000$ & T10 & 6.1 \\
\hline $9 / 5 / 2000$ & T10 & 6.1 \\
\hline $9 / 8 / 2000$ & T10 & 3.0 \\
\hline $9 / 11 / 2000$ & T10 & 6.1 \\
\hline $9 / 12 / 2000$ & T10 & 3.0 \\
\hline $9 / 20 / 2000$ & T10 & 6.1 \\
\hline $9 / 25 / 2000$ & T10 & 6.1 \\
\hline $9 / 20 / 2010$ & T6 & 9.0 \\
\hline $9 / 21 / 2010$ & T7 & 10.0 \\
\hline $10 / 18 / 2010$ & T9 & 6.0 \\
\hline $10 / 19 / 2010$ & T11 & 6.0 \\
\hline $10 / 27 / 2010$ & T6 & 12.5 \\
\hline $10 / 27 / 2010$ & T11 & 12.5 \\
\hline $3 / 28 / 2011$ & T6 & 12.0 \\
\hline $3 / 28 / 2011$ & T11 & 12.0 \\
\hline $4 / 27 / 2011$ & T7 & 12.5 \\
\hline $4 / 27 / 2011$ & T9 & 12.5 \\
\hline $8 / 23 / 2011$ & T9 & 12.0 \\
\hline $8 / 23 / 2011$ & T7 & 12.0 \\
\hline $8 / 29 / 2011$ & T6 & 12.0 \\
\hline $8 / 29 / 2011$ & T11 & 12.0 \\
\hline $10 / 31 / 2011$ & T7 & 24.5 \\
\hline $12 / 21 / 2011$ & T6 & 14.0 \\
\hline Total & & 270.6 \\
\hline & & \\
\hline & & \\
\hline
\end{tabular}

Table 1-1: Lime slurry injection dates and amounts 

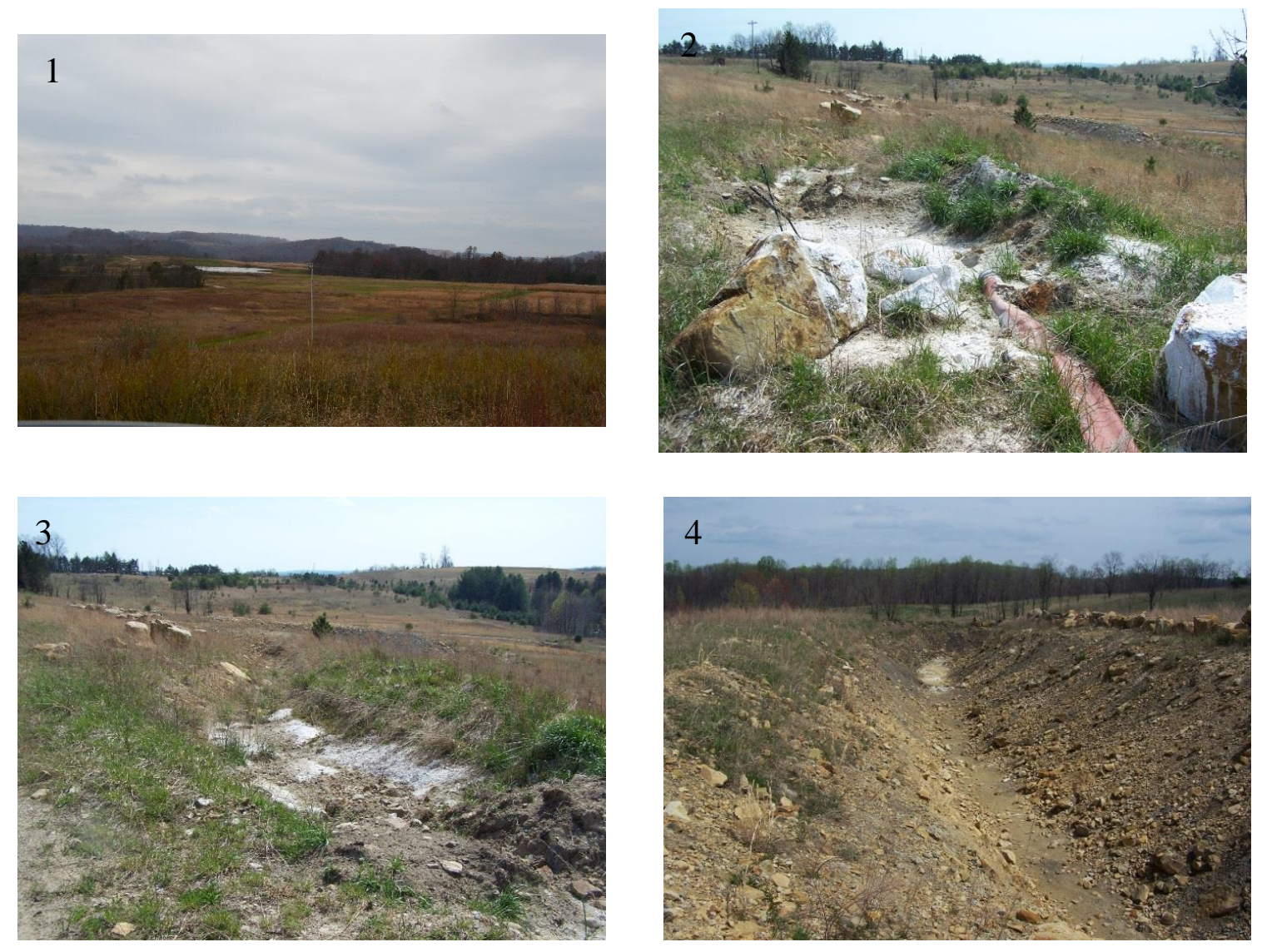

Figure 1-6: (1) View of the DLM X bench from south to north, (2) the mixing trench at T6, (3) the connector ditch at T6, (4) the infiltration trench T6. 
Sincock (1998) found preferred flow paths in mine-spoil aquifers are similar to the interconnected workings of karst aquifers. Hawkins (2004) concluded that the driving force for groundwater flow in a mine-spoil aquifer is the geometry of the pit floor.

Donovan et al (1997) characterized the geochemistry of the X Bench and noted the effect of alkaline recharge from the sludge disposal pond. They concluded that the flux of alkalinity from sludge disposed in the pond was insufficient to neutralize the acidity generated in the aquifer. Daly (1998) conducted a geochemical investigation of the Y bench at the DLM site, where hydrated lime $\left(\mathrm{Ca}(\mathrm{OH})_{2}\right)$ slurry was used to flood a lolying sludge disposal area. While neutralization of acid and precipitation of metals was observed within the aquifer, the plume of alkalinity did not extend to the aquifer's discharges. This was attributed to rapid precipitation of calcite as a result of increased alkalinity and elevated $\mathrm{CO}_{2}$ pressures. Barker (1997) monitored response to in situ injections at a West Virginia spoil aquifer into which sodium hydroxide was injected through wells. Carbonate precipitation, induced by $\mathrm{CO}_{2}$-induced carbonation of alkalinity, was also observed here. Barker also discussed how reaction products formed during injections play a role in buffering acidity and establishing $\mathrm{pH}$ plateaus.

\subsection{Background}

\subsubsection{Geochemistry of Acid Mine Drainage}

Due to heterogeneity in geochemical conditions found at coal mines, groundwater can vary both spatially and temporally (Cravotta and Hilgar, 2000). The initiation of acid conditions associated with coal mining comes from the oxidation of pyrite. The complex process, which involves chemical and biological reactions, begins with the oxidation of 
pyrite by oxygen in the presence of water (Blowes et al, 2003). The products of the reaction are one mole of $\mathrm{Fe}^{2+}$, two moles of $\mathrm{SO}_{4}{ }^{2+}$ and two moles of $\mathrm{H}^{+}$(Eq. 1).

$$
\mathrm{FeS}_{2}+\frac{7}{2} \mathrm{O}_{2}+\mathrm{H}_{2} \mathrm{O} \rightarrow \mathrm{Fe}^{2+}+2 \mathrm{SO}_{4}{ }^{2-}+2 \mathrm{H}^{+}
$$

After the dissolution of pyrite, $\mathrm{Fe}^{2+}$ may be further oxidized to $\mathrm{Fe}^{3+}$ (Eq. 2).

$$
\mathrm{Fe}^{2+}+\frac{1}{4} \mathrm{O}_{2}+\mathrm{H}^{+} \leftrightarrow \mathrm{Fe}^{3+}+\frac{1}{2} \mathrm{H}_{2} \mathrm{O}
$$

$\mathrm{Fe}^{3+}$ can then further oxidize pyrite (Eq. 3) to produce 16 moles of $\mathrm{H}^{+}$or it can precipitate as a number of different hydrous ferric oxides (HFO). These include amorphous goethite, ferrihydrite and schwertmannite (Nordstrom, 2011).

$$
\begin{aligned}
& \mathrm{FeS}_{2}+14 \mathrm{Fe}^{3+}+8 \mathrm{H}_{2} \mathrm{O} \rightarrow 15 \mathrm{Fe}^{2+}+2 \mathrm{SO}_{4}{ }^{2-}+16 \mathrm{H}^{+} \\
& \mathrm{Fe}^{3+}+3 \mathrm{H}_{2} \mathrm{O} \rightarrow \mathrm{Fe}(\mathrm{OH})_{3}+3 \mathrm{H}^{+}
\end{aligned}
$$

Neutralization of acidity produced by pyrite oxidation and metal hydrolysis involves a series of reactions with mineral phases (Blowes and Ptacek, 1994; Jurjovec et al., 2002). The sequence of phases may vary depending on the neutralizing minerals present, but generally begins with carbonate minerals which buffer the system to an approximate $\mathrm{pH}$ of 6.0. Equilibrium of water chemistry with amorphous aluminum hydroxide or gibbsite will buffer the $\mathrm{pH}$ between 4.0 and 4.5. At lower levels of alkalinity, hydrous ferric oxides such as goethite or ferrihydrite are favored and will maintain a $\mathrm{pH}$ of 2.5 to 3.5 .

Aluminosilicate minerals such as chlorite, illite, smectite, kaolinite, muscovite and biotite may dissolve to some extent throughout the neutralization process (Blowes et al., 2003). Silicate dissolution occurs most rapidly at lower $\mathrm{pH}$ and increases 
concentrations of $\mathrm{Al}^{3+}, \mathrm{K}^{+}, \mathrm{Mg}^{2+}, \mathrm{Ca}^{2+}$ or $\mathrm{Mn}^{2+}$. Although dissolution initially consumes $\mathrm{H}^{+}$, this hydrogen-ion acidity may be realized later in the water evolution through hydrolysis of $\mathrm{Al}^{3+}$ and $\mathrm{Mn}^{2+}$ to form precipitates (Rose and Cravotta, 1998).

Metal-laden water contains high concentrations of $\mathrm{Fe}^{2+}, \mathrm{Fe}^{3+}, \mathrm{Al}^{3+}$ and $\mathrm{Mn}^{2+}$ which contribute to the total aqueous acidity. Acidity is defined as the equivalent sum of acids titratable with a strong base (Stumm and Morgan, 1996). In metal rich mine water of near-neutral $\mathrm{pH}$, metals can decrease the $\mathrm{pH}$ and add to the hydrogen-ion acidity upon hydrolysis (Kirby and Cravotta, 2005). Therefore, Equation 5 is used to incorporate acidity from metals and hydrogen where metal concentrations are in mg/l (Rose and Cravotta, 1998).

$$
\operatorname{Acidity}(\mathrm{mg} / \mathrm{lasCaCO} 3)=50\left[1000\left(10^{-p H}\right)+\frac{\left[2\left(\mathrm{Fe}^{2+}\right)+3\left(\mathrm{Fe}^{3+}\right)\right]}{56}+\frac{2(\mathrm{Mn})}{55}+\frac{3(\mathrm{Al})}{27}\right]
$$

\subsubsection{Chemistry of Lime Slurry}

Hydrated lime $\left(\mathrm{Ca}(\mathrm{OH})_{2}\right)$, or portlandite, is a common alkaline mineral used for the neutralization of acid mine drainage (Johnson and Hallberg, 2005). It is produced by Hydration of $\mathrm{CaO}$, formed by combustion of calcite (Whittington, 1996).

$$
\mathrm{CaO}+\mathrm{H}_{2} \mathrm{O} \rightarrow \mathrm{Ca}(\mathrm{OH})_{2}
$$

With enough water, $\mathrm{Ca}(\mathrm{OH})_{2}$ is dissolved with two moles of $\mathrm{OH}^{-}$and one mole of $\mathrm{Ca}^{2+}$ being released.

$$
\mathrm{Ca}(\mathrm{OH})_{2} \rightarrow \mathrm{Ca}^{2+}+2 \mathrm{OH}^{-}
$$

When added to AMD, strong caustic alkalinity $\left(\mathrm{OH}^{-}\right)$increases $\mathrm{pH}$ and precipitates metals, neutralizing their acidity. 
The solubility product $\left(\mathrm{K}_{\mathrm{sp}}\right)$ of $\mathrm{Ca}(\mathrm{OH})_{2}\left(4.68 \times 10^{-6}\right)$ indicates it is slightly soluble (Whittington, 1996). Solubility may be increased or decreased depending on impurities present in solution. For example, $\mathrm{SO}_{4}{ }^{2-}$ is known to dramatically decrease solubility while it can be doubled by organics. With alkaline injection, it is useful to dissolve the greatest amount of lime possible for incorporation of alkalinity into the aquifer. Therefore, efficiency would be dependent on effective dosing rates based on hydrated lime dissolution in a particular solution.

\subsection{Organization of the Thesis}

This document is divided into four sections with the first section covering study area history and background information. The second section includes an investigation into the DLM X bench to understand the post mining hydrochemical evolution of the mine-spoil. Section three includes the development of a methodology for estimating acid loads using natural cubic splines. Sections two and three have individual methods, results and conclusions and are treated as individual papers within the thesis. The final section outlines overall conclusions and recommendations for future research. 


\title{
2: Delineation of Hydrochemical Facies at an Acid-Producing Mine-Spoil Aquifer
}

\begin{abstract}
Estimating post mining water quality at surface mines is complex, and influenced by the hydrochemical evolution of the mine spoil. Agglomerative hierarchical clustering was used to group hydrochemistry of the DLM X bench sampled in 1994, 1999, 2010 and 2012. Results were mapped to demonstrate spatial variations in response to reclamation attempts over time. Spatial patterns were discerned over multiple sampling periods and indicated that aquifer chemistry has continued to evolve over this period. The results show that induced alkaline recharge temporarily neutralized acidity and can have lasting effects on groundwater chemistry in mine spoil.
\end{abstract}

\subsection{Introduction}

The hydrochemical evolution of acid producing mine spoils has important implications for post mining water treatment (Cravotta and Hilgar, 2000). Chemical evolution of discharge from surface mines is dependent on many factors including overburden lithology. Calcareous lithologic units have greater acid neutralizing potential for post mining reclamation (Callaghan et al., 2000). Pyrite $\left(\mathrm{FeS}_{2}\right)$ dissolution is primarily responsible for the initial acid production in coal overburden (Brady et al., 200). Although this mineral makes up only a small percentage of the mineralogy, it has a significant impact on water chemistry in the absence of neutralizing minerals. Therefore, the presence of carbonate minerals and mineralogy of the overburden are the most important factors controlling post mining water quality (Kleinmann et al., 2000). 
Mining reclamation practices and special handling of acid producing materials can also affect long term water quality. Alkaline amendments, such as limestone, are often used to increase the neutralizing potential of mine spoil (Kleinmann et al., 2000). Applying undesirable mining practices such as improper handling of acid producing material and non-concurrent reclamation can further degrade post mining water quality (Callaghan et al., 2000).

Mapping of "hydrochemical facies" is a method used to synthesize chemical characteristics of similar waters based on common geochemical processes (Back, 1966). Progressive reactions along groundwater flow paths can create spatial patterns in water chemistry useful in determining geochemical and transport processes (Freeze and Cherry, 1979; Glynn and Plummer, 2005). Statistical methods have been used to delineate geochemically-similar regions in aquifers and can be useful in determining chemical change over time (Mathes and Rasmussen, 2006).

\subsection{Study Area and Background}

To examine the spatial and temporal geochemical evolution of groundwater from the DLM X bench, a graphical time series was created for 1994 to 2012. Water samples were collected by different investigators from groundwater monitoring wells (Fig. 1-4) on the following dates 10/19/1994, 11/4/1994, 6/1/1999, 6/2/1999, 6/17/2010, 8/6/2010, 10/13/2012 and 10/25/2012. The 1994 samples indicated a complex system of preferential flow paths, acid-producing and acid-buffering reactions (Donovan et al., 1996). The 2010 samples were interpreted to reflect a weathering environment that was 
closed to atmospheric $\mathrm{CO}_{2}$. Following alkaline injections occurring in 2000 (Table 1-1), improved water chemistry was observed in the vicinity of Trench T10 (Neuman, 2010).

Many protocols exist for graphical representation of geochemical data (Zaporozec, 1972). Standard plots used for displaying natural waters (i.e. Piper diagram) are less useful for acid-sulfate water (Kirby and Cravotta, 2005). Additionally, acid mine drainage can exhibit high concentrations of other cations due to acid buffering reactions that occur throughout the flow system (Blowes and Ptacek, 1994). Due to the complexity and number of important variables in these waters, a variation of the star plot (R Core Team, 2012) was chosen to graphically represent geochemistry.

\subsection{Purpose and Objectives}

The purpose of this investigation was to examine the spatial and temporal variability in groundwater chemistry at the DLM X bench from 1994 to 2012 and interpret groundwater evolution in response to remediation. It was chosen because it has been the focus of a variety of remediation efforts including the injection of lime slurry (Sturm, 1986; Avery, 1997; Donovan et al., 1997; Neuman, 2013).

Specific objectives include:

1. Classification into clusters of water chemical analysis across all four sampling periods.

2. Mapping of hydrochemical facies for the four sampling periods.

3. Graphical representation of water chemical evolution during the study period. 


\subsection{Methodology}

\subsubsection{Classification of Water Types}

Agglomerative hierarchical clustering by Ward's Minimum Variance Method (Han and Kamber, 2001) was used to classify groups according to water chemistry over different sampling periods. Cations used in the cluster analysis included $\mathrm{Ca}, \mathrm{Mg}, \mathrm{Al}$, total $\mathrm{Fe}$, and total $\mathrm{Mn}$. Anions used for the cluster analysis included alkalinity and $\mathrm{SO}_{4}$. Cation concentrations were determined by inductively coupled plasma-atomic emission spectrometry (USEPA, 1994) and $\mathrm{SO}_{4}$ by ion chromatography (USEPA, 1993). Alkalinity was measured in the field by the $\mathrm{H}_{2} \mathrm{SO}_{4}$ standard titration method (ASTM, 2006). The measured values of all analytes were converted to units of milliequivalent per liter (meq/l) prior to clustering, and $\mathrm{pH}$ was used as measured in the field. Lab and field chemistry for all samples can be found in Appendix A.

Agglomerative hierarchical clustering is a "bottom-up" approach in which objects are sequentially merged into larger and larger clusters based on dissimilarity (Han and Kamber, 2001). Measurements were standardized by z-scores and Euclidean distance was used for dissimilarity between objects. Cluster analysis and dendrogram creation were performed using the hclust() function in R (R Core Team, 2012). An example script used for cluster analysis is presented in Appendix B. Standard boxplots were used to visualize the distribution of chemical constituents within clusters for normality and outliers (Han and Kamber, 2001). An example script for the creation of boxplots in $\mathrm{R}$ is found in Appendix B. 


\subsubsection{Graphical Representation of Water Chemistry}

Star plots were used to graphically display chemical compositions of individual samples. The customizable stars() function in $\mathrm{R}$ was employed because of its ability of display any number of parameters (Murrell, 2006). Star plots created in this study incorporate $\mathrm{pH}$, alkalinity, $\mathrm{SO}_{4}, \mathrm{Ca}, \mathrm{Mg}, \mathrm{Al}, \mathrm{Fe}$, and $\mathrm{Mn}$, the major chemical constituents in the aquifer. These plots, along with the sample's cluster group, were compiled for all available sampling periods.

Star plots display multiple variables for a single observation with each segment of the star representing one variable (Murrell, 2006). Chemical data were arranged into rows representing individual sample locations and columns representing chemical constituents. Each sample was identified by "X” (i.e., X-Bench), a 2 digit well I.D. and a 2 digit year ID These data were imported into $\mathrm{R}$ as a matrix, normalized between 0 and 1 , and the stars() function was applied (R Core Team, 2012). An example of script for star plots in $\mathrm{R}$ is located in Appendix B.

\subsection{Results}

\section{$\underline{\text { 2.5.1 Classification of Clusters }}$}

The results of cluster analysis are graphically displayed by the dendrogram in Figure 2-1 and four different clusters were discriminated into groups. Figure 2-2 shows box plots for $\mathrm{pH}$, alkalinity, and ion concentration within different cluster groups. The box represents the interquartile range from the $25^{\text {th }}$ to $75^{\text {th }}$ percentile, with the middle line representing the $50^{\text {th }}$ percentile (median). The whiskers represent the high and low values 
that fall within 1.5 times the interquartile range. Extreme values that fall outside the $1.5 \mathrm{X}$ interquartile range are outliers and represented by dots (Han and Kamber, 2001).

Table 2-1 contains the average values of the four groups determined from cluster analysis and a brief description of their chemical compositions. Group 1 exhibits the highest $\mathrm{pH}$, measurable alkalinity and also the lowest values for metals and sulfate. Group 2 has a low $\mathrm{pH}$ and little to no alkalinity. It also has low concentrations of metals, $\mathrm{Ca}, \mathrm{Mg}$ and $\mathrm{SO}_{4}$. Group 3 has similar $\mathrm{pH}$ and alkalinity as Group 2, but exhibits higher values for $\mathrm{Ca}, \mathrm{Mg}$ and $\mathrm{SO}_{4}$. Group 4 has the lowest $\mathrm{pH}$ and no measurable alkalinity. It also exhibits the highest concentrations for metals, $\mathrm{Ca}, \mathrm{Mg}$ and $\mathrm{SO}_{4}$.

\subsubsection{Spatial Interpretation of Hydrochemical Facies}

Hydrochemical facies created using the results of cluster analysis were mapped to examine spatial variations over time in response to reclamation attempts (Figure 2-3). The legend for this figure shows (a) the cluster group (symbol) and (b) the well ID (label in symbol). The 23 samples taken in 1994 are uniformly distributed across the aquifer, with the largest gap occurring in the south (Figure 2-3). The chemistry is dominated by Groups 3 and 4 with two anomalies (X24 and X15) from Group 1 showing localized sources of alkalinity. The 17 samples taken in 1999 (Figure 2-3) are more concentrated at the northern part of the aquifer. The predominant group in 1999 was Group 3, though Groups 1 and 2 increased in frequency from 1994. Localized areas of alkalinity occur at wells X9, X15 and X44. The 28 samples taken in 2010 are widely distributed although no wells were sampled near the sludge pond or on the west border. The predominant groups in 2010 were 1 and 2, with a higher frequency in Group 1 than in previous sampling 
periods. In 2012, 16 samples were collected around and down gradient from areas that received alkaline injections in 2010 and 2011 (Table 1-1). Gaps in sampling distribution occur in the northeast, southeast and west areas of the aquifer. The predominant groups in 2012 are 1 and 3, which suggests that regions of alkaline and acidic water coexist in the aquifer.

\subsubsection{Graphical Representation of Water Chemistry}

Star plots were used as a visual times series for chemical evolution over different sampling dates (Fig. 2-4). Group 4 (highest metals and lowest $\mathrm{pH}$ ) is not present after 1999. Some wells shifted groups between sampling dates; for example, X7 changed from Group 2 in 2010 to Group 3 in 2012. Also, Ca had its highest concentrations in 2012 and lowest in 2010. In 1994 and 1999, Ca was similar in concentration to Mg but greatly exceeded it in 2012. It is interpreted that these high Ca concentrations relate to reclamation activities between $2010-2012$.

\subsection{Summary and Conclusion}

Four distinct groups were discriminated based on cluster analysis of water chemistry (pH, alkalinity, $\mathrm{Ca}, \mathrm{Mg}, \mathrm{SO}_{4}, \mathrm{Al}, \mathrm{Fe}$, and $\mathrm{Mn}$ ). The clusters were used to map hydrochemical facies, analogous to the method of Robins et al. (2005). Spatial patterns over multiple sampling periods indicate that aquifer chemistry has continued to evolve over this period. 


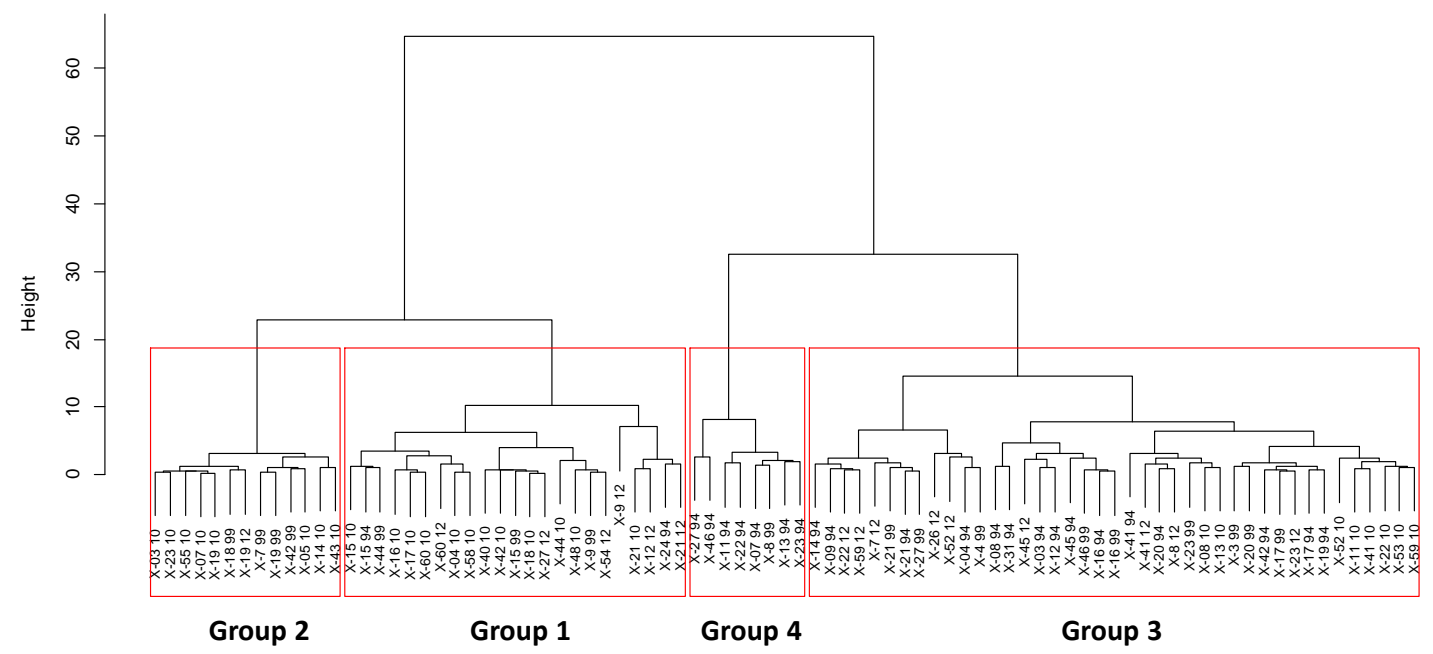

Figure 2-1: Dendrogram interpreted from cluster analysis with cluster groups 

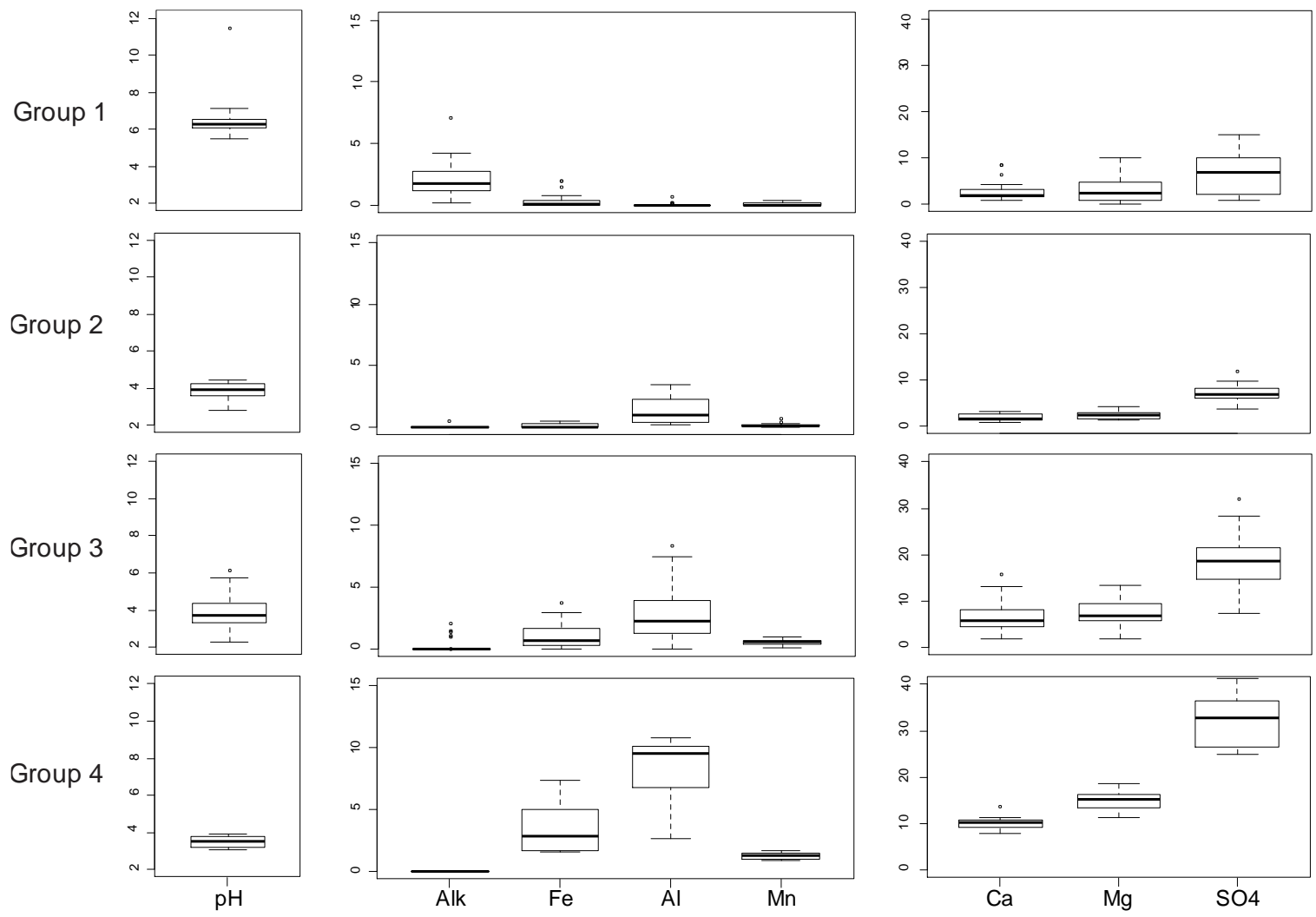

Figure 2-2: Box plots showing chemistry of cluster centroids by group. All concentrations are in $\mathrm{meq} / \mathrm{l}$ and $\mathrm{pH}$ is in standard units. 


\begin{tabular}{|c|c|c|c|}
\hline Group & \multicolumn{2}{|c|}{ Average (meq/l) } & Description \\
\hline \multirow{8}{*}{1} & $\mathrm{pH}$ & 6.55 & \multirow{8}{*}{$\begin{array}{l}\text { Group } 1 \text { has the highest } \mathrm{pH} \text { of all clusters. It has measurable } \\
\text { alkalinity, low mineralization and low values for metal } \\
\text { cations. }\end{array}$} \\
\hline & Alk & 2.18 & \\
\hline & $\mathrm{Fe}$ & 0.38 & \\
\hline & $\mathrm{Al}$ & 0.06 & \\
\hline & $\mathrm{Mn}$ & 0.12 & \\
\hline & $\mathrm{Ca}$ & 2.92 & \\
\hline & $\mathrm{Mg}$ & 2.99 & \\
\hline & SO4 & 6.52 & \\
\hline & & & \\
\hline & $\mathrm{pH}$ & 3.88 & \\
\hline & Alk & 0.04 & \\
\hline & $\mathrm{Fe}$ & 0.19 & Group 2 is characterized by low mineralization and metals. \\
\hline 2 & $\mathrm{Al}$ & 1.39 & What sets it apart from Group 1 is its low $\mathrm{pH}$ negligible \\
\hline & $\mathrm{Mn}$ & 0.23 & \\
\hline & $\mathrm{Ca}$ & 1.95 & \\
\hline & $\mathrm{Mg}$ & 2.43 & \\
\hline & $\mathrm{SO} 4$ & 7.35 & \\
\hline & & & \\
\hline & $\mathrm{pH}$ & 3.49 & \\
\hline & Alk & 0.18 & \\
\hline & $\mathrm{Fe}$ & 1.06 & \\
\hline 3 & $\mathrm{Al}$ & 2.78 & Group 3 is similar to Group 2 but has a greater mineralized \\
\hline & $\mathrm{Mn}$ & 0.56 & \\
\hline & $\mathrm{Ca}$ & 6.29 & \\
\hline & $\mathrm{Mg}$ & 7.59 & \\
\hline & $\mathrm{SO} 4$ & 18.33 & \\
\hline & & & \\
\hline & $\mathrm{pH}$ & 3.43 & \\
\hline & Alk & 0.00 & \\
\hline & $\mathrm{Fe}$ & 3.52 & Group 4 is characterized by low $\mathrm{pH}$ and has the highest \\
\hline 4 & $\mathrm{Al}$ & 8.33 & values for acidity, calcium, magnesium, and sulfate. \\
\hline & $\mathrm{Mn}$ & 1.26 & \\
\hline & $\mathrm{Ca}$ & 10.28 & \\
\hline & $\mathrm{Mg}$ & 14.95 & \\
\hline & $\mathrm{SO} 4$ & 32.27 & \\
\hline
\end{tabular}

Table 2-1: Description of cluster groups. $\mathrm{pH}$ is in standard units and all analytes are in meq/l. 


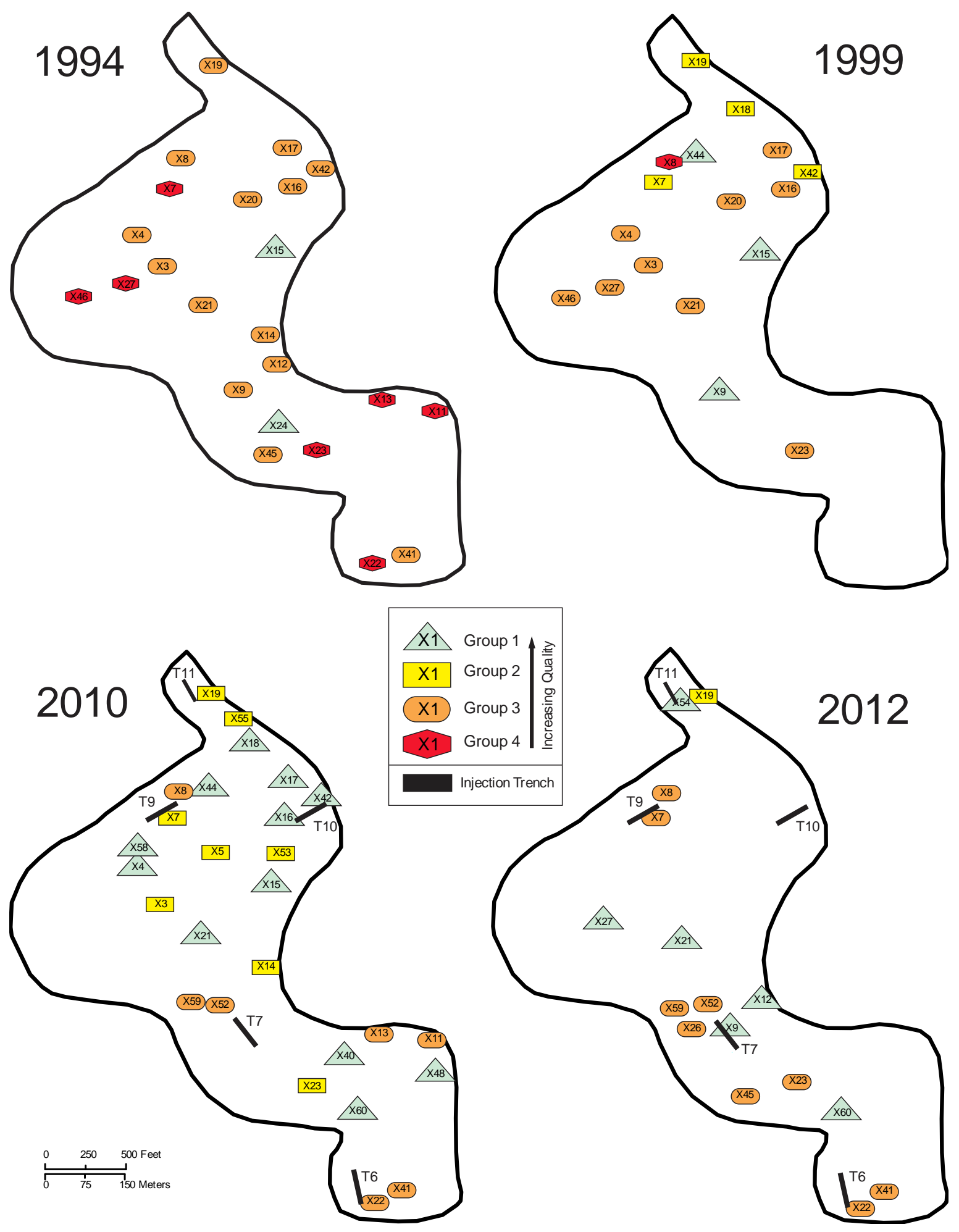

Figure 2-3: Hydrochemical facies of the DLM X bench 


\begin{tabular}{|c|c|c|c|c|c|c|c|c|c|}
\hline Year & \multirow{2}{*}{1994} & \multirow{2}{*}{1999} & \multirow{2}{*}{2010} & \multirow{2}{*}{2012} & Year & \multirow{2}{*}{1994} & \multirow{2}{*}{1999} & \multirow{2}{*}{2010} & \multirow{2}{*}{2012} \\
\hline Well ID & & & & & Well ID & & & & \\
\hline$X-3$ & $A_{3}$ & $\star$ & ${ }_{2}$ & & $X-23$ & & A & 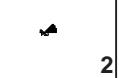 & ${ }_{3}$ \\
\hline$X-4$ & & $\infty$ & $\infty$ & & $X-24$ & $\Delta$ & & & \\
\hline$X-5$ & & & 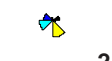 & & $X-26$ & & & & $\infty$ \\
\hline$X-7$ & & \% & 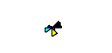 & $\infty$ & $X-27$ & & $\Delta$ & & $\Lambda$ \\
\hline$X-8$ & 5 & A & $\Delta$ & $\star$ & $X-40$ & & & 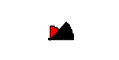 & \\
\hline$X-9$ & A & $\Delta$ & & & $X-41$ & & & 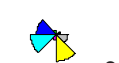 & $A$ \\
\hline$X-11$ & & & $\Delta$ & & $X-42$ & 4 & * & 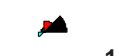 & \\
\hline$X-12$ & A & & & 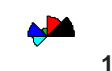 & $X-44$ & & $\#$ & 2 & \\
\hline$X-13$ & & & $\Delta$ & & $X-45$ & 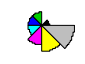 & & & $\infty$ \\
\hline$X-14$ & $\star$ & & $\star$ & & $X-46$ & & A & & \\
\hline$X-15$ & 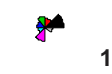 & $\sim$ & $*_{1}$ & & $X-48$ & & & $\boldsymbol{\Delta}$ & \\
\hline$X-16$ & $\mathbb{A}_{3}$ & $\Delta$ & $* 1$ & & $X-52$ & & & $y_{3}$ & $\phi_{3}$ \\
\hline$X-17$ & 8 & $\Delta$ & $\infty$ & & $X-53$ & & & $\star \nabla_{3}$ & \\
\hline$X-18$ & & & $\triangle 1$ & & X-54 & & & & $\Delta$ \\
\hline$X-19$ & ${ }_{3}$ & $\$$ & $\infty$ & 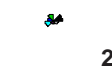 & $X-55$ & & & $\infty$ & \\
\hline$X-20$ & $\forall>_{3}$ & $\phi$ & & & $X-58$ & & & $\infty$ & \\
\hline$X-21$ & $\star_{3}$ & 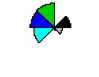 & $\lambda$ & $d$ & $X-59$ & & & $\rightarrow 3$ & 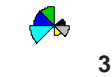 \\
\hline X-22 & $y_{4}$ & & $\star$ & $\Leftrightarrow$ & $X-60$ & & & 1 & 1 \\
\hline
\end{tabular}

Figure 2-4: Star plot matrix with cluster group number in the lower right corner 
During 1994 and 1999, alkalinity was found at only a few locations and ascribed to either (a) dispersion of alkaline sludge leaking from the disposal pond (Frysinger, 1995; Donovan et al., 1997), or (b) limestone amendment on the pit floor during mining and site reclamation (Kleinmann et al., 2000). Clearly, alkalinity and $\mathrm{pH}$ substantially increased in a number of wells at some point after 1999, when Group 1 waters (highest $\mathrm{pH}$ and alkalinity) became more numerous and, in some portions of the spoil, ubiquitous. Wells in this group (X16, X17, X18, and X42) are especially prominent in the vicinity of the T10 trench, which received an estimated 79 tons of lime in 2000 (Neumann, 2013). These wells showed increases in $\mathrm{pH}$ and alkalinity as well as decreases in metals (Fig. 24).

Trench T7 received 4 lime slurry injections in 2010 and 2011 (Table 1-1) which influenced down gradient wells X9, X26 and X52. The highest values for pH, alkalinity, and $\mathrm{Ca}$ were observed at these wells in 2012, and equilibrium calculations show saturation with calcite $\left(\mathrm{CaCO}_{3}\right)$ and brucite $\left(\mathrm{Mg}(\mathrm{OH})_{2}\right)$ in X9. Although X52 remained in the same cluster group from 2010 to 2012, it underwent a large increase in Ca (Fig. 2-4). The results show that the alkaline injections of 2010-2011 influenced groundwater chemistry in downgradient wells. 


\title{
3: Quantification of Acid Loads Discharging from a Phreatic Mine-Spoil Aquifer
}

\begin{abstract}
Quantifying acid loads is an important step in development and implementation of acid mine drainage remediation projects. This investigation developes a methodology for estimating acid loads discharging from surface mines using natural cubic splines. Lowfrequency chemistry was interpolated, resampled and multiplied by higher-frequency datalogger-based flow measurements to produce high-frequency acid load datasets at five discharges. Cross-correlation of high-frequency datasets with sequentially lowerfrequency datasets showed an exponential decrease in correlation as the number of days between flow measurements was increased by resampling. Results show that this method useful for increasing the accuracy of acid load estimates using continuously-sampled flow measurements and automated data collection equipment.
\end{abstract}

\subsection{Introduction}

The accurate determination of acidity and acid loads discharging from surfacemine backfills, is a practical tool for treatment and remediation. Acid-producing constituents that require treatment in addition to hydrogen ion include iron, aluminum and manganese (Skousen et al, 2000; Ziemkiewicz et al, 2003; Canty and Everet, 2006). The interval for sampling of water chemistry to estimate loads depends on the specific project requirements and desired accuracy, but generally ranges from daily to quarterly (Cravotta and Hilgar, 2000). Single samples cannot describe variations in geochemistry 
related to seasonality. More informed estimates can be made only with higher frequency data for both flow and chemistry.

Acid loads (mg/s) are calculated by multiplying acidity $\left(\mathrm{mg} / \mathrm{l}\right.$ as $\left.\mathrm{CaCO}_{3}\right)$ with flow (1/s). Very high-frequency flow estimates may be straightforwardly obtained with data-logger pressure transducers (Weight, 2004). High -frequency flow data is needed because flows may demonstrate higher variability than concentrations (Cravotta and Hilgar, 2000). Resampling the lower frequency chemistry to the frequency of the flows allows calculation of high-frequency acid loads.

\subsection{Study Area and Background}

Hydrochemical data were collected at the DLM X bench for this study from July 2010 to October 2012. The DLM X bench was chosen because it produces acid mine drainage and its flows are easily quantified. Five Parshall flumes equipped with pressure transducers (Fig. 1-4) were installed and used to estimate discharge from the aquifer. Aqueous chemistry was sampled at the flumes and acidity was calculated from analytical results.

Mathematical approximations can be used to create high frequency datasets to accommodate inconsistent sampling routines. Cubic splines have been successfully utilized in a number of applications (Bickley, 1968; Dougherty et al, 1989; Cao et al, 2006). Splines employ piece-wise, nth order polynomials to interpolate between datapoints with continuous functions. The data points where adjacent polynomials converge are referred to as knots (Chapra and Canale, 1988). Applying cubic splines to low- 
frequency acid concentrations allows for resampling and integration of high-frequency loads which can be used in remediation strategies.

\subsection{Purpose and Objectives}

The purpose of this investigation is to develop a methodology to approximate acid loads using widely-spaced sample intervals for chemistry but high-frequency measurement intervals for flow. This will be accomplished by (a) interpolating hydrochemical time-series data and re-sampling it to high-frequency and (b) numerically integrating acid loads on the higher-frequency interval. Specific objectives include:

1. Collection of geochemical and hydrological data for the purpose of calculating acid loads

2. Approximate data using cubic splines to establish continuous flow and acid load datasets

3. Quantify acid loads over specified intervals with numerical integration techniques

\subsection{Methodology}

\subsubsection{Collection of Geochemical and Hydrological Data}

Acid Mine Drainage (AMD) was collected for chemical analysis at the intake of five Parshall flumes (Fig. 1-4) with a clean $60 \mathrm{cc}$ syringe rinsed in the sample source prior to collection. The sample was then filtered through a $0.45 \mu \mathrm{m}$ cellulose membrane filter and deposited in two $60 \mathrm{ml}$ polyethylene sample bottles. One of the bottles contained $1 \mathrm{ml}$ of concentrated nitric acid and was labeled as FA (filtered acidified), 
while the other bottle was labeled FU (filtered un-acidified). The FA sample analyzed for dissolved cation concentrations by inductively coupled plasma-atomic emission spectrometry (USEPA, 1994). Anion concentrations were determined by ion chromatography using the FU sample (USEPA, 1993).

Field parameters measured at the intake of the flume included specific conductance, temperature, $\mathrm{pH}$, Eh and alkalinity. Specific conductance $(\mu \mathrm{s} / \mathrm{cm})$ was measured with a YSI EC300 conductivity meter. Temperature $\left({ }^{\circ} \mathrm{C}\right)$ and $\mathrm{pH}$ were measured with a Hanna HI 9025 pH meter. Alkalinity was determined by the standard titration method (ASTM, 2006). Oxidation reduction potential (mv) was measured with a YSI pH/ORP meter. Eh was determined using Zobel's solution as a reference (Nordstrom and Wilde, 2005).

Discharge data was obtained from the 1-inch Parshall flumes using a sealed water level logger measuring absolute pressure to an accuracy of $\pm 0.12 \mathrm{psi}$ and averaged on a daily interval. The absolute pressure is converted to hydraulic head by subtracting local atmospheric pressure and multiplying by $2.308 \mathrm{ft} / \mathrm{psi}$. This head is then used to estimate flow using a rating equation :

$$
Q=c h^{n}
$$

where $Q$ is the flow in $\mathrm{ft}^{3} / \mathrm{sec}, h$ is head in feet, $c$ is the Parshall flume coefficient and $n$ is the Parshall flume exponent (Dodge et al, 2001). For the flumes used in this study the value of $c$ equaled 0.338 and $n$ equaled 1.55 . 


\subsubsection{Resampling of Geochemical Data using Cubic Splines}

Natural cubic splines were used in this study to resample unequally spaced water chemical samples that exhibited large variations from one point to the next. These conditions can induce oscillations in higher order polynomials where cubic splines can provide more acceptable approximations (Chapra and Canale, 1988). Natural cubic spline functions meet the following conditions: (1) the function values must be equal at their interior knots; (2) the first and last functions must pass through the endpoints; (3) the first derivatives at interior knots must be equal; (4) the second derivatives at interior knots must be equal; (5) the second derivative at the end knots must equal zero (Chapra and Canale, 1988). The spline() function in $\mathrm{R}$ was used to create natural cubic splines from the data (R Core Team, 2012). An example of script for cubic splines in $\mathrm{R}$ is located in Appendix B.

Cross-correlation was used to analyze the effect of decreasing flow measurement frequency. Cross-correlation is a measure of similarity between two datasets with values close to 1 identifying them as well correlated (Kachigan, 1986). Cubic splines were applied to sequentially lower frequency flow measurements, resampled at a daily interval, and cross-correlated with the daily flow dataset for Flume P9. Intervals between flow measurements included 1, 2, 3, 5, 7, 10, 14 and 30 days.

\subsubsection{Numerical Integration to Determine Acid Loads}

Cubic splines represent a series of continuous functions which may be integrated using a Gauss-Kronrod quadrature technique (Gander and Gautschi, 2000). Gaussian quadrature utilizes multiple $\mathrm{x}$-values to discretize the area under the function. Such 
integration can generate accurate integrated results within a specified tolerance (Chapra and Canale, 1988). Integration of acid loads was completed in R using the quadgk() function from the pracma package (R Core Team, 2012). An example of script for numerical integration in $\mathrm{R}$ is found in Appendix B.

\subsection{Results}

\subsubsection{Continuous Flows and Acid Loads}

Figure 3-1 shows acidity concentrations $\left(\mathrm{mg} / \mathrm{l}\right.$ as $\left.\mathrm{CaCO}_{3}\right)$ for each flume resampled to a daily interval. This dataset was then multiplied by daily average flow (1/s) (Fig. 3-2) to calculate daily acid loads (mg/s). Gaps in the time series represent intervals when flow data were corrupt or not measured. The highest flows were at P10 and the lowest flows were at C1. Cubic splines were applied to daily acid loads (Fig. 3-3) to produce continuous acid loads for presentation and integration. These datasets follow a similar pattern to the flow datasets which shows that acid loads are directly influenced by flow volume. 

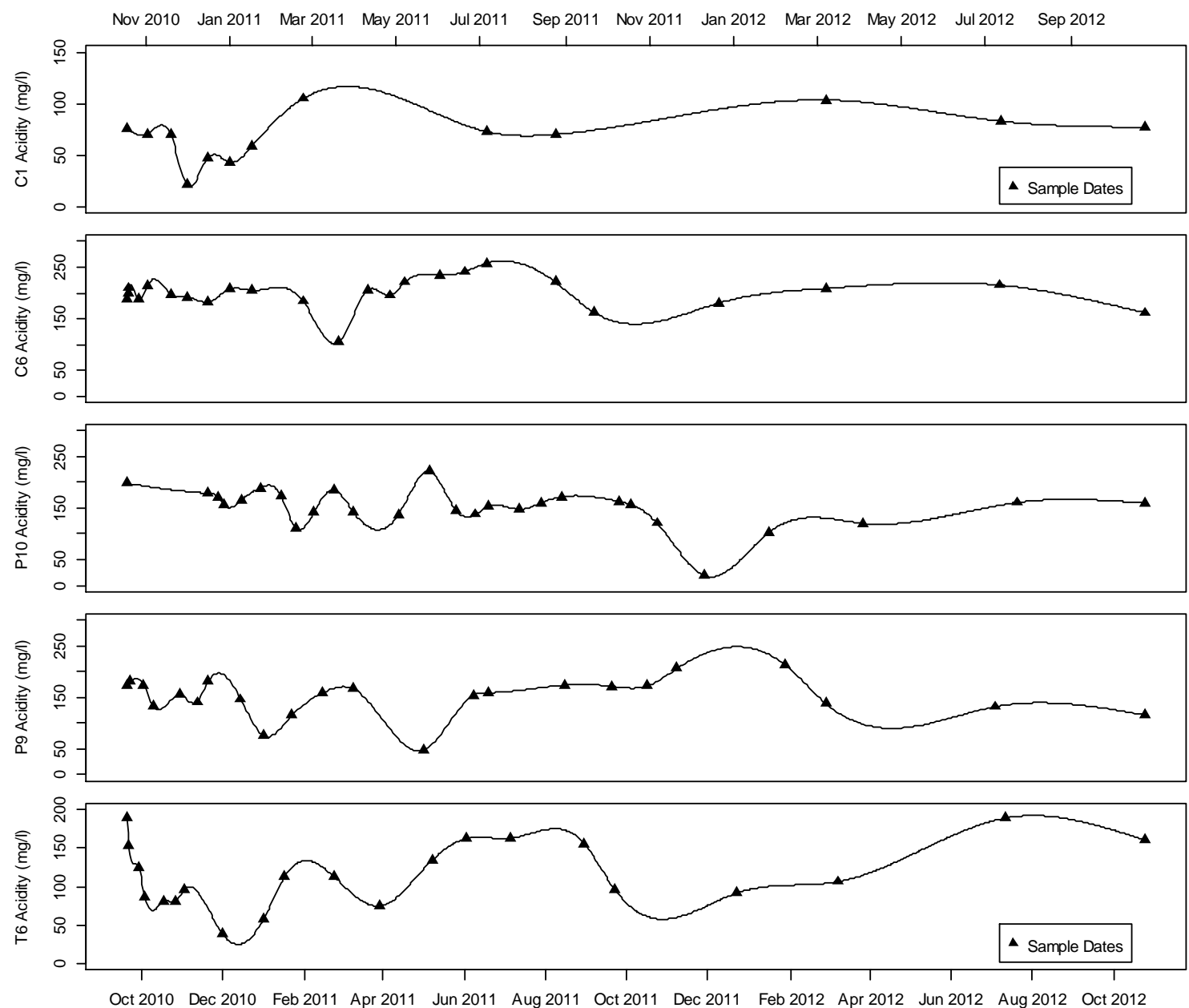

Figure 3-1: Interpolated acid concentrations $\left(\mathrm{mg} / \mathrm{l}\right.$ as $\left.\mathrm{CaCO}_{3}\right)$ at five flume sites. Triangles represent dates of chemistry samples. 

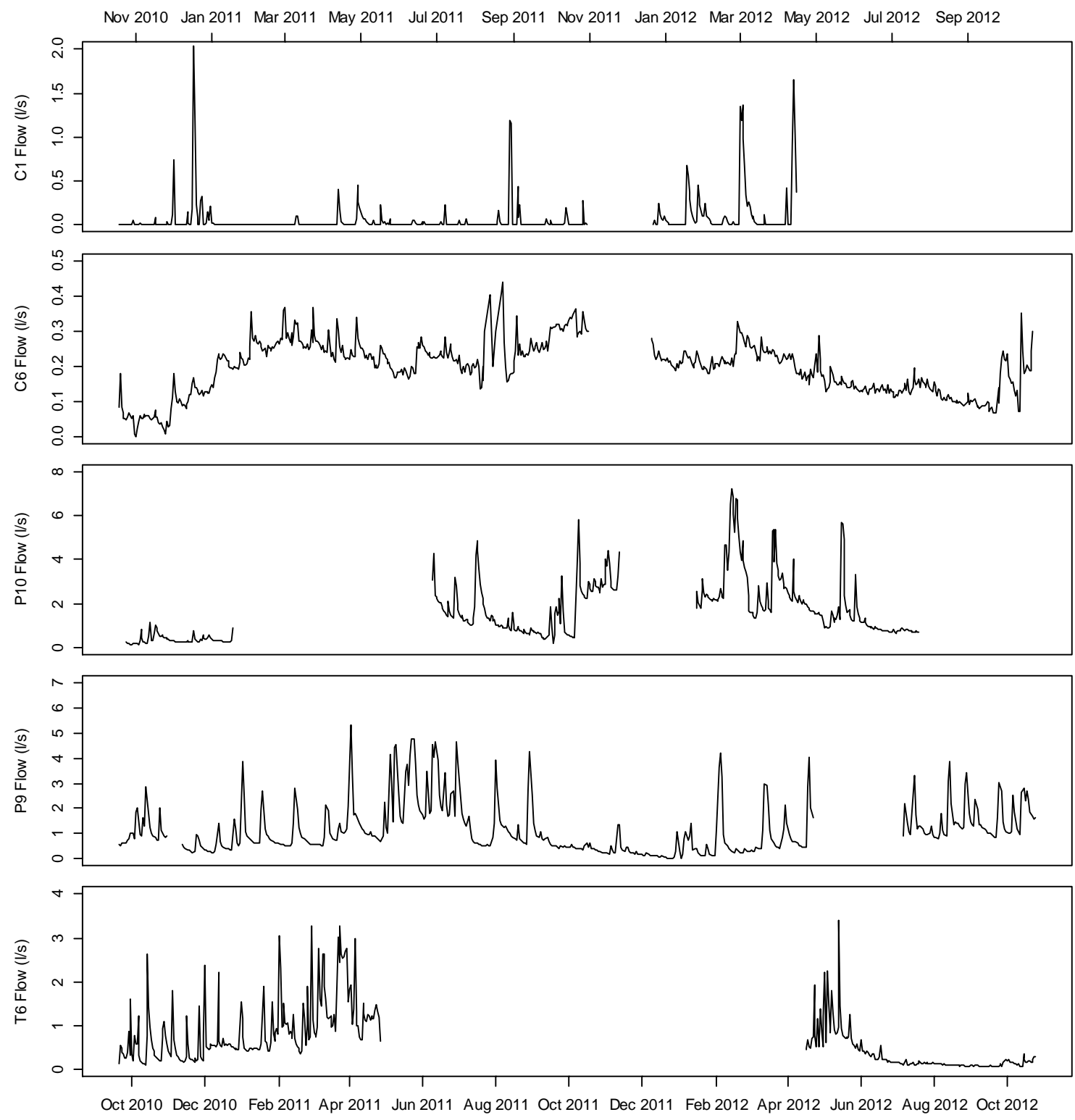

Figure 3-2 Flow (1/s)at five flume sites. Gaps represent intervals in which flow was not measured. 

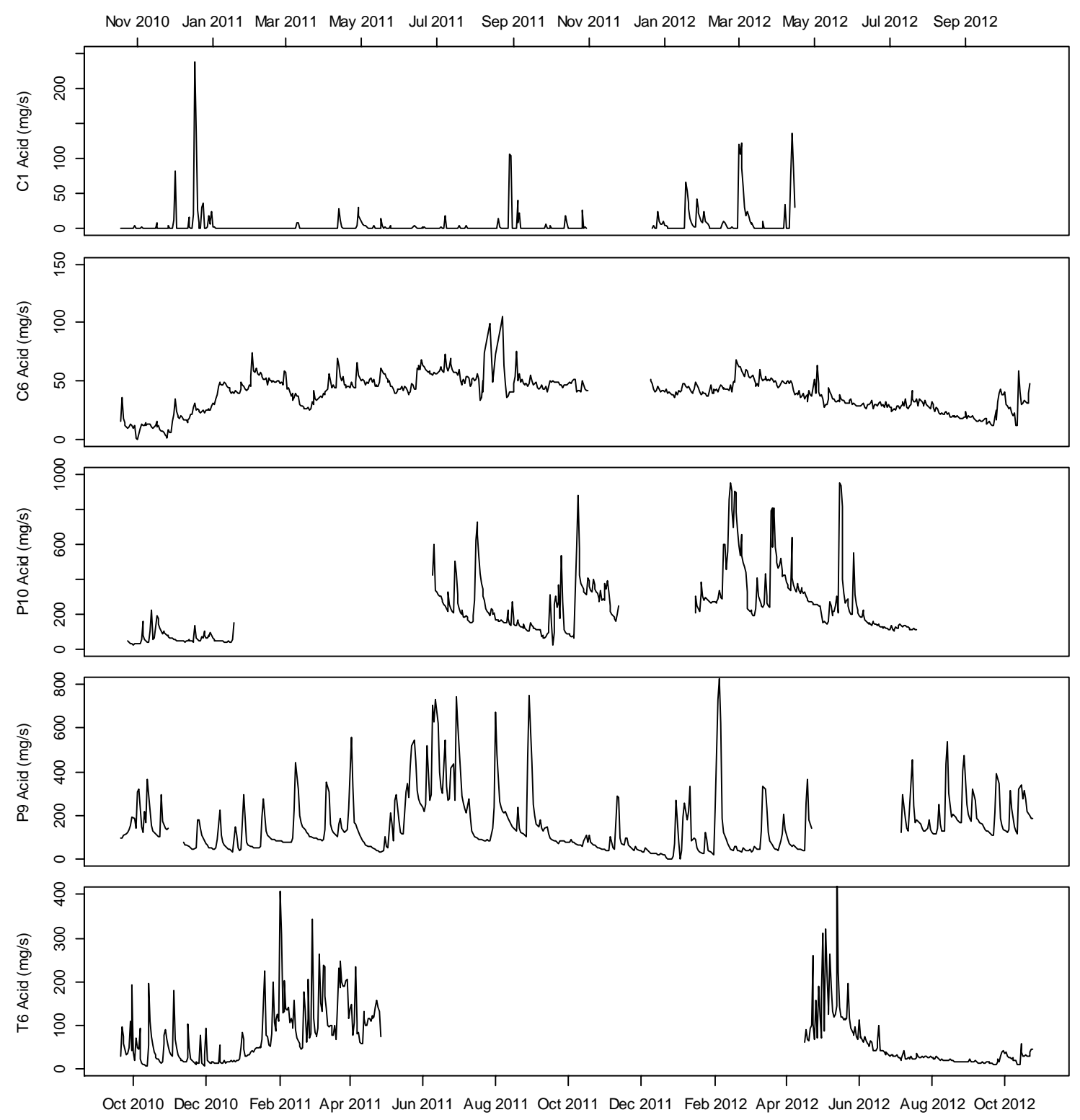

Figure 3-3: Acid loads (mg/s) for each flume. 
Cross-correlation showed an exponential decrease as the number of days between flow measurements was increased (Fig. 3-4). At the high frequency interval (1 day) a correlation coefficient of 1.0 was obtained. At 10 days between measurements, the correlation drops to below 0.6. The correlation between daily acid loads and flow measurements also follows an exponential decay model (Fig. 3-5). At daily flow intervals, the acid loads and flow time-series correlate at 0.931. At flow measurement intervals of five days, the correlation between daily acid loads and flow drops to 0.699. The results show that flow influences acid loads, and as flow measurement frequency decreases the accuracy of acid load estimation decreases.

\subsubsection{Monthly Acid Loads}

Figure 3-6 shows the monthly mass flux of acidity discharging from the $\mathrm{X}$ bench over a two year period. Time periods in which loads were not computed are shown, and calculations that only included partial months are displayed by grey bars. Flume P10 had the highest flows the highest acid loads. The lowest acid loads are discharged from Flume C1-2, and Flume C6 has the most even distribution of loads over all months.

Table 3-1 shows the integrated acid loads for every month of the study at each flume. The grey areas represent averaged values, and were needed to compute an approximated acid load for the entire study period. January of 2012 had the highest acid load of the study period, followed by March 2011 and March 2012. The final value (41.9 tons of acid as $\mathrm{CaCO}_{3}$ ) is equivalent to $7.61 \times 10^{5}$ hydrogen ion equivalents. Assuming ideal mixing conditions, it would take 31.1 tons of $\mathrm{Ca}(\mathrm{OH})_{2}$ to neutralize the acidity discharged from the aquifer during the study period. 


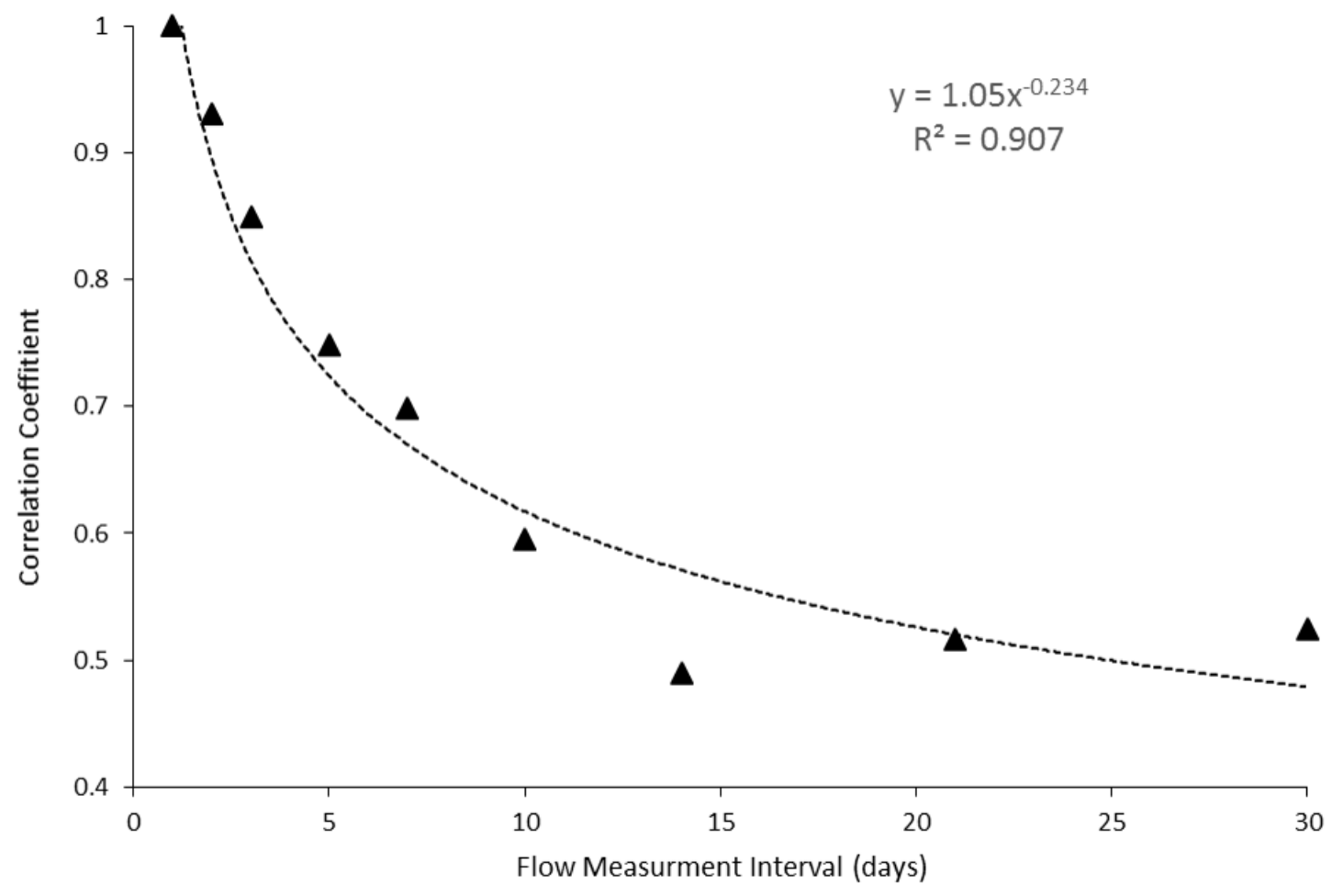

Figure 3-4: Correlation coefficients for high frequency flow and flow measured at decreasing frequency. 


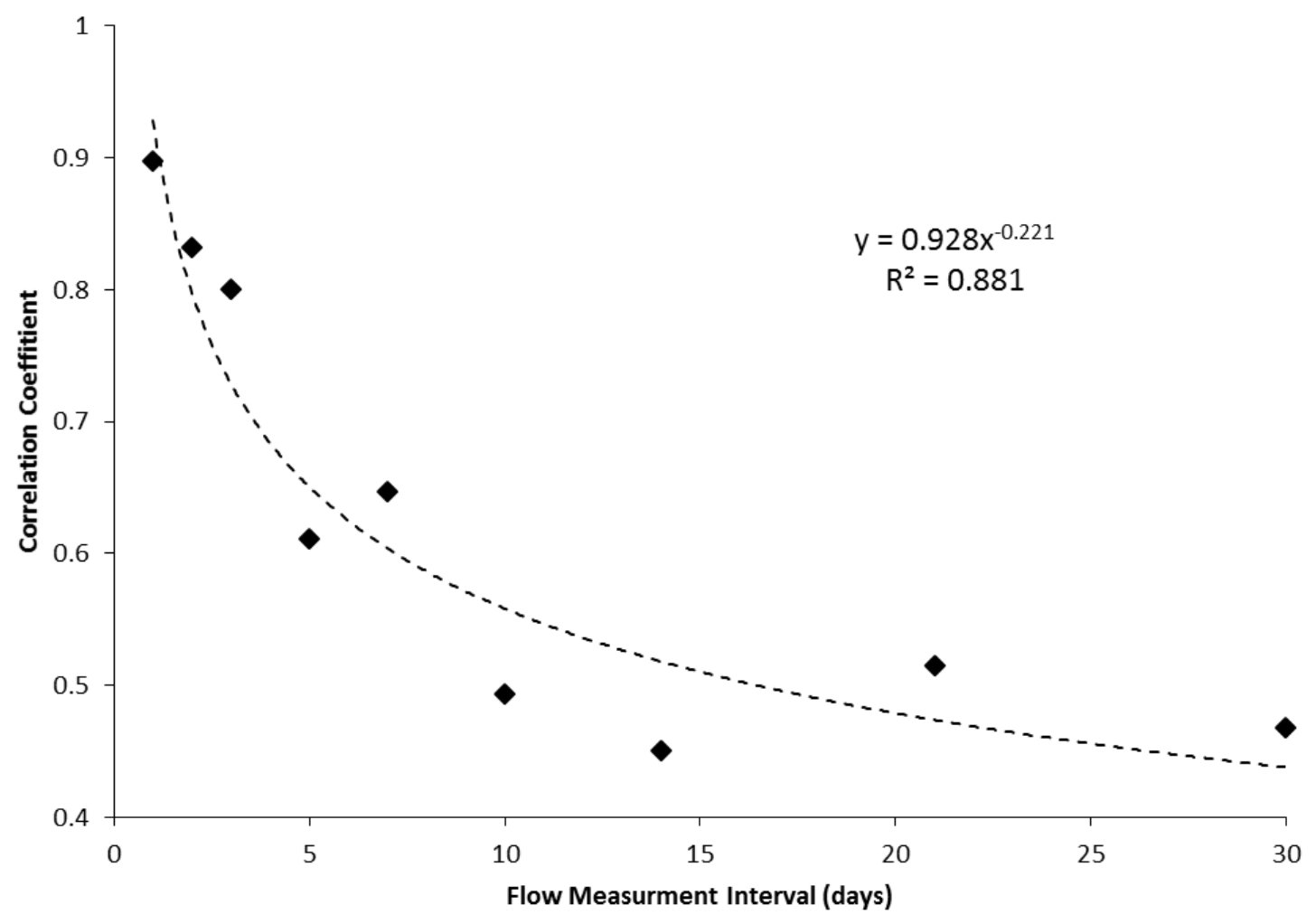

Figure 3-5: Correlation coefficients for high frequency acid loads and acid loads calculated with decreasing flow frequency 

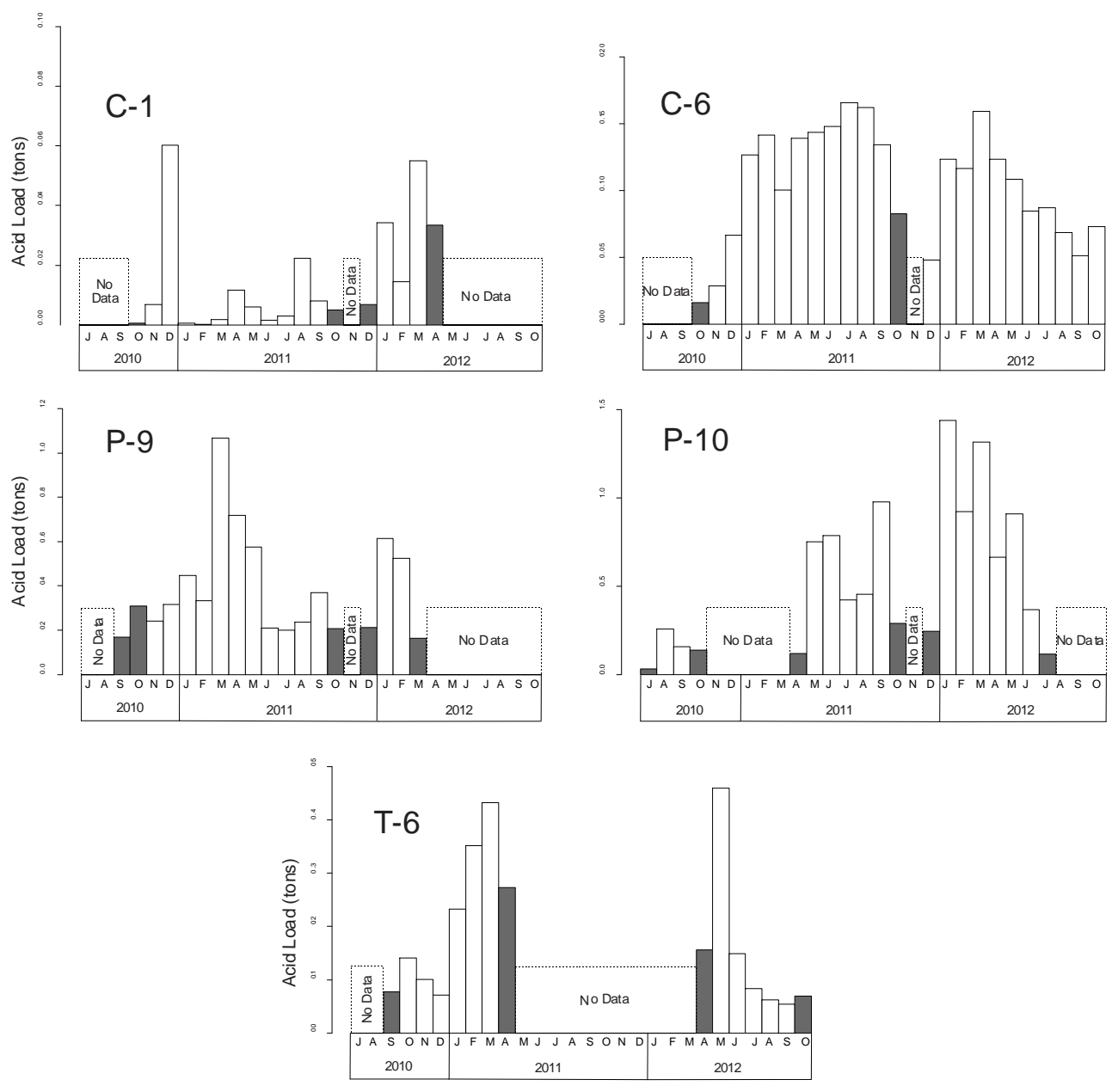

Figure 3-6: Monthly acid loads. Grey bars indicate partial months. 


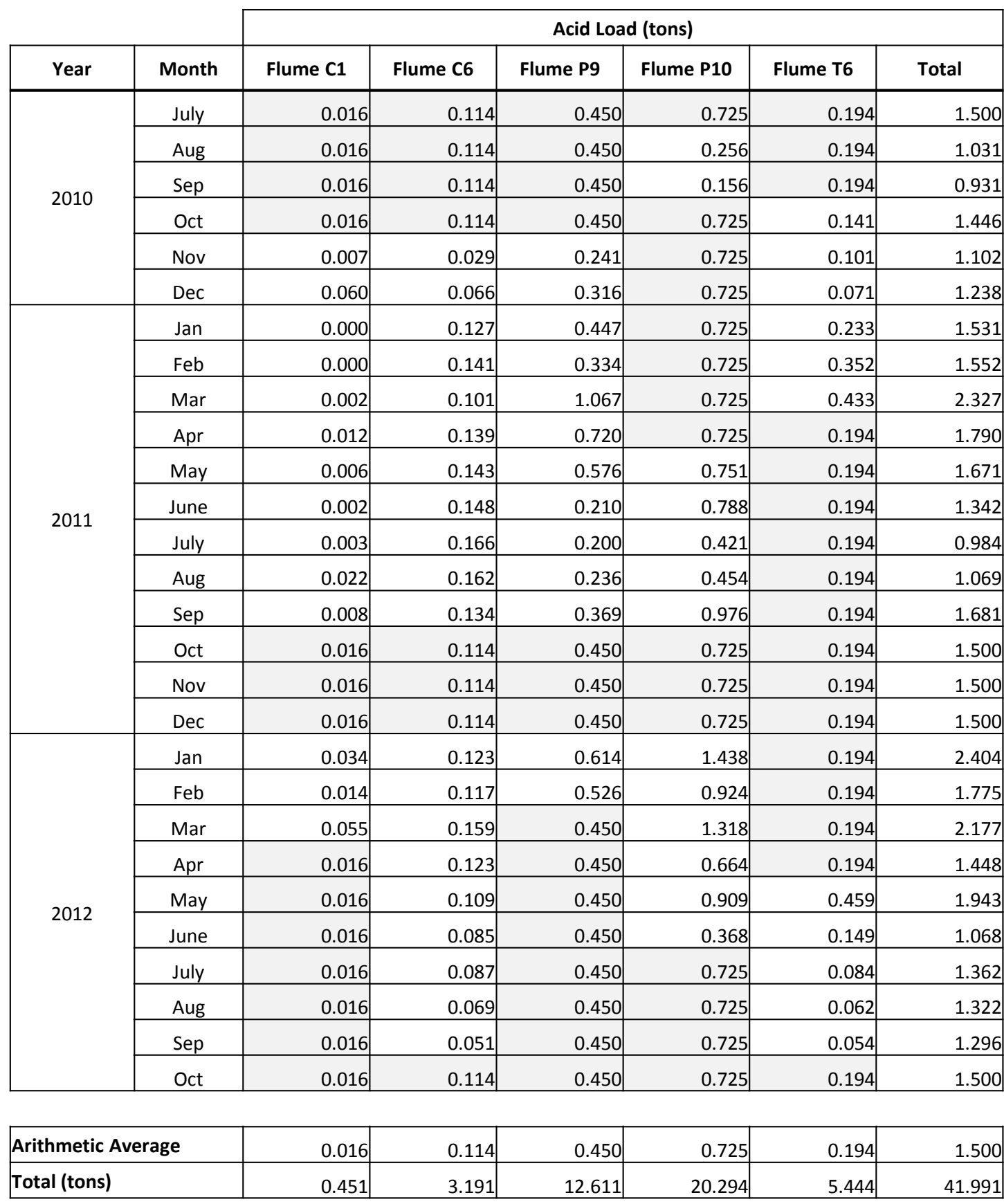

Table 3-1: Acid discharged from the DLM X bench over the study period. Grey boxes represent values averaged from integrated loads. Acid loads are in units of tons as $\mathrm{CaCO}_{3}$. 


\subsection{Summary and Conclusion}

Chemical loads of acidity represent information commonly needed to design treatment plans for AMD. Acid loads requires estimates of both flow and total acidity. Flow (discharge rate) can be effectively sampled at high frequency using data-logger based pressure transducers and primary structures such as flumes (Weight, 2004). Water chemistry, however, is often observed to vary over much longer time intervals (Cravotta and Hilgar, 2000) and therefore is commonly sampled at much lower frequency. To calculate loads, resampling of water chemistry to higher frequency is needed.

This investigation was undertaken to give a case history of how these two datasets (flow and chemistry) might be paired to produce robust acidity estimates. It was also undertaken to show the loss of information resulting from coarsening the resampling interval from daily estimates to lower frequencies. Results show that natural cubic splines are useful in resampling hydrochemical time series data to estimate solute concentrations at higher frequencies than originally sampled. The frequency at which flow is measured limits the accuracy of acid load estimates, and high frequency measurements are needed to account for variability in discharge. 


\section{5: Conclusions and Future Research}

\subsection{Conclusions}

1. Cluster analysis was useful for interpretation of hydrochemical facies and showed that DLM groundwater changed from primarily acidic in 1994 to more alkaline in 2012. Maps of hydrochemistry indicated that aquifer chemistry continued to evolve over the study period.

2. Wells down gradient from trenches $\mathrm{T} 10$ and $\mathrm{T} 7$ showed an increase in $\mathrm{pH}$, alkalinity and $\mathrm{Ca}$ concentrations. It was clear that this change was influenced by alkaline injections which neutralized acidity in groundwater chemistry.

3. Natural cubic splines were useful for approximating hydrochemical time series. These functions provided a means of obtaining continuous, integrable functions that showed changes in acid concentrations. They further allowed for visualization of acid loads over time and numerical integration of loads.

4. High frequency flow measurements are needed to account for variability in discharge and the frequency at which flow is measured limits the accuracy of acid load estimates.

\subsection{Future Research}

1. A major contribution to the future of in situ injection of hydrated lime at DLM would be to understand the optimal dosage rate of $\mathrm{Ca}(\mathrm{OH})_{2}$. This would maximize the amount of dissolved alkalinity introduced to the aquifer. 
2. The hydrogeology of the sludge disposal pond should be investigated to understanding the effect high density alkaline sludge has on local groundwater flow.

3. Current mineralogy is needed at the $\mathrm{X}$ bench for the confirmation of inverse modeling. A full vertical mineral profile, and in depth investigation into the role of the vadose zone, should be conducted for greater understanding of acid producing and consuming reactions.

4. A reaction-transport model should be implemented for the complete quantification of the system. This includes transient simulations of lime slurry injections and inclusion of preferred flow paths. 


\section{References Cited}

Aljoe, W.W., and Hawkins, J.W., 1993. Neutralization of acidic discharges from abandoned underground coal mines by alkaline injection. U.S. Bureau of Mines Report of Investigations 9468, 37 pp.

American Society for Testing and Materials (ASTM), 2006. Standard test methods for acidity or alkalinity of water: D 1067-06. In: Annual Book of ASTM Standards, ASTM International, West Conshocken, PA, 8 pp.

Avery, W.A., 1997. Recharge characteristics of an Appalachian mine spoil aquifer. Unpublished M.S. Thesis, Department of Geology and Geography, West Virginia University, $133 \mathrm{pp}$.

Back, W., 1966. Hydrochemical facies and ground-water flow patterns in northern part of Atlantic Coastal Plain. U.S. Geological Survey Professional Paper 498-A, 42 p.

Barker, R.E., 1997. Reaction geochemistry of an acidic mine-spoil aquifer following well injection of sodium hydroxide. Unpublished M.S. Thesis, Department of Geology and Geography, West Virginia University, $122 \mathrm{pp}$.

Bickley, W.G., 1968. Piecewise cubic interpolation and two-point boundary problems. The Computer Journal, v. 11, no. 2, p. 206-208.

Blowes, D.W., and Ptacek, C.J., 1994. Acid neutralization mechanisms in inactive mine tailings. In: Jambor, J.L., and Blowes, D.W. (eds.), Environmental Geochemistry of Sulfide Mine Wastes, v. 22, Waterloo, Ontario, p. 272-292.

Blowes, D.W., Ptacek, C.J., Jambor, J.L., and Weisener, C.G., 2003. The Geochemistry of Acid Mine Drainage. In: Lollar, B.S., (ed.), Treatise on Geochemistry, v. 9, p. 149-204.

Brady, K., Hornberger, R., Chisholm, W., and Sames, G., (2000) Chapter 3: Hydrology of the Appalachian bituminous coal basin, in Kleinmann, R.L.P. ed. Prediction of Water Quality at Surface Coal Mines, ADTI: Morgantown, West Virginia University, National Mine Land Reclamation Center, p.54.

Callaghan, T., Brady, B.C., Chisholm, W., and Sames, G., (2000) Chapter 3: Hydrology of the Appalachian bituminous coal basin, in Kleinmann, R.L.P. ed. Prediction of Water Quality at Surface Coal Mines, ADTI: Morgantown, West Virginia University, National Mine Land Reclamation Center, p.54. Canty, G.A., and Everett, J.W., 2006. Alkaline injection technology: Field demonstration. Fuel, v. 85 , p. 2545-2554. 
Cao, J., Valois, M.F., and Goldberg, M.S., 2006. An S-Plus function to calculate relative risks and adjusted means for regression models using natural splines. Computer Methods and Programs in Biomedicine, v. 84, p. 58-62.

Caruccio, F.T., Geidel, G., and Williams, R., 1984. Induced alkaline recharge zones to mitigate acidic seeps. University of Kentucky, Office of Engineering Services, (Bulletin) UKY BU: p. 43-47.

Chapra, S.C., and Canale, R. P., 1988. Numerical Methods for Engineers, Second Edition. McGraw, New York, p. 287-297, 505.

Cravotta, C.A., and Hilgar, G.M., (2000) Considerations for chemical monitoring at coal mines, in Kleinmann, R.L.P. ed. Prediction of Water Quality at Surface Coal Mines, ADTI: Morgantown, West Virginia University, National Mine Land Reclamation Center, p. 203-207.

Cravotta, C.A., and Kiby, C.S., 2004. Effects of abandon coal mine drainage on streamflow and water quality in the Shamokin Creek Basin, Northumberland and Columbia Counties, Pennsylvania, 1999-2001: U.S. Geological Survey WaterResources Investigations Report 03-4311, 63 p.

Daly, M.H., 1998. Hydrochemical response of an acid-producing mine spoil aquifer to induced alkaline recharge. Unpublished M.S. Thesis, Department of Geology and Geography, West Virginia University, 137 pp.

Dodge, R., Clemmens, A., and Replogle, J., 2001. Water measurement manual: U.S. Bureau of Reclamation water resources technical publication, chap. 8, p. 148.

Donovan, J.J., Frysinger, K.W., and Maher, T.P., 1997. Geochemical response of acid groundwater to neutralization by alkaline recharge. Aquatic Geochemistry, v. 2, p. 227-253.

Donovan, J..J., 1998. Chemical and fluid mass balance evolution in acid-generating coal spoil piles. Unpublished report to National Mine Lands Reclamation Center, July 1998, $140 \mathrm{pp}$.

Dougherty, R.L., Edelman, A., and Hyman, J.M., 1989. Nonnegativity, monotonicity, or convexity-preserving cubic and quintic Hermite interpolation. Mathematics of Computaion, v. 52, no. 186, p. 471-494.

Freeze, R.A, and Cherry, J.A., 1979. Groundwater. Prentice Hall, Englewood Cliffs, p. 247-253.

Frysinger, K.F., 1995. Large-scale groundwater flow characteristics of a heterogeneous Appalachian minespoil aquifer. Unpublished M.S. Thesis, Department of Geology and Geography, West Virginia University, $132 \mathrm{pp}$. 
Gander, W., and Gautschi, W., 2000. Adaptive quadrature - revisited. BIT Numerical Mathematics, v. 40, no. 1, p. 84-101.

Glynn, P.D., and Plummer, L.N., 2005. Geochemistry and the understanding of groundwater systems. Hydrogeology Journal, v. 13. p. 263-287.

Han, J., and Kamber, M., 2001. Data mining, Concepts and Techniques. Academic Press, San Diego, p. 211, 354-356.

Hawkins, J.W., 2004. Predictability of surface mine spoil hydrologic properties in the Appalachian Plateau. Groundwater, v. 42, no. 1, p. 119-125.

Johnson, D.B., and Hallberg, K.B., 2005. Acid mine drainage remediation options: a review. Science of the Total Environment, v. 338, p. 3-14.

Jurjovec, J., Ptacek, C.J., and Blowes, D.W., 2002. Acid neutralization mechanisms and metal release in mine tailings: A laboratory column experiment. Geochimica et Cosmochimica Acta, v. 66, no. 9, p. 1511-1523.

Kachigan, S.K., 1986. Statistical Analysis: An Interdisciplinary Introduction to Univariate and Multivariate Methods. Radius Press, New York, p. 204, 219, 223 226.

Ketchum, J.N., 1998. Recharge dynamics of a perched phreatic aquifer. Unpublished M.S. Thesis, Department of Geology and Geography, West Virginia University, $129 \mathrm{pp}$.

Ketchum, J.N., Donovan, J.J., and Avery, W.H., 2000. Recharge characteristics of a phreatic aquifer as determined by storage accumulation. Hydrogeology, v. 8, p. 579-593.

Kirby, C.S., and Cravotta, C.A., 2005, Net alkalinity and net acidity1 :Theoretical considerations. Applied Geochemistry, v. 20, p. 1920-1940.

Kleinmann, R.L., Hornberger, R., Leavitt, B., and Hyman, D.M., (2000) Chapter1: Introduction and Recommendations, in Kleinmann, R.L.P. ed. Prediction of Water Quality at Surface Coal Mines, ADTI: Morgantown, West Virginia University, National Mine Land Reclamation Center, p. 1-7.

Maher, T.P. Jr., 1996. Hydrogeologic properties of an extremely heterogeneous minespoil aquifer analyzed using radial flow tests. Unpublished M.S. Thesis, Department of Geology and Geography, West Virginia University, 108 pp.

Mathes, E.S., and Rasmussen, T.C., 2006. Combining multivariate statistical analysis with geographic information systems mapping: a tool for delineating groundwater contamination. Hydrogeology, v. 14, p. 1493-1507. 
Murrell, P., 2006. $R$ graphics: Computer science and data analysis series. Taylor and Francis, Boca Raton, p. 5.

Neumann, T., 2013. Chemical characteristics of groundwater within a 30 year old mine spoil: the DLM site Alton, WV. Unpublished M.S. Thesis, Department of Geology and Geography, West Virginia University, 38 pp.

Nordstrom, D.K., and Wilde, F.D., 2005, Reduction-Oxidation Potential (electrode method) (ver. 1.2): U.S. Geological Survey Techniques of Water-Resources Investigations, book 9, chap. A6, sec. 6.5, July 2006, accessed May 15, 2013, from http://water.usgs.gov/owq/FieldManual/Chapter6/6.5_v_1.2.pdf

Nordstrom, D.K., 2011. Hydrochemical processes governing the origin, transport and fate of major and trace elements from mine wastes and mineralized rock to surface waters. Applied Geochemistry, v. 26, p. 1777-1791.

R Core Team, 2012. R: A language and environment for statistical computing. $\mathrm{R}$ Foundation for Statistical Computing, Vienna, Austria, ISBN 3-900051-07-0, URL http://www.R-project.org/.

Robins, N.S., Davies, J., Farr, J.L., and Calow, R.C., 2006. Combining multivariable statistical analysis with geographic information systems mapping: a tool for delineating groundwater contamination. Hydrogeology Journal, v. 14, no. 8, p.1493-1507.

Rose, A.W., and Cravotta, C.A., 1998. Chapter 1: Geochemistry of coal mine drainage. in Brady, K.B.C., Smith, M.W., and Schueck, J. (eds.), Coal Mine Drainage Prediction and Pollution Prevention in Pennsylvania: Harrisburg, PA, PA Dept. of Environ. Protection, p. 1-1-1-21.

Sincock, M.J., 1998. Quantification of preferred-flow pathways and velocities in an extremely heterogeneous mine spoil aquifer. Unpublished M.S. Thesis, Department of Geology and Geography, West Virginia University, 107 pp.

Skousen, J.G., Sexstone, A., and Ziemkiewcz, P.F., 2000. Acid mine drainage controls and treatment. In: Barnhisel, R.I., Darmody, R.G., and Daniels, W.L. (eds.), Reclamation of Drastically Disturbed Lands. American Society of Agronomy and American Society for Surface Mining and Reclamation. Agronomy, No. 41. p. 131-168.

Stumm, W., and Morgan, J.J., (1996). Aquatic Chemistry: Chemical Equilibria and Rates in Natural Waters, $3^{\text {rd }}$ Ed. Wiley, New York, p. 10, 163-172, 357-358.

Sturm Environmental Services, 1986. Proposed mitigation plan for acid mine drainage, Alton project. Unpublished report to WV Division of Environmental Protection, Bridgeport, WV, May 1886, 145 pp. 
US Environmental Protection Agency (USEPA) 2012. Method 6010C, Inductively coupled plasma-atomic emission spectrometry. In: Test Methods for Evaluating Solid Waste, Physical/Chemical Methods. US Environm. Prot. Agency EPA SW846

US Environmental Protection Agency (USEPA) 1994. Method 200.7, Determination of metals and trace elements in water and wastes by inductively coupled plasmaatomic emission spectrometry. In: Methods for the determination of metals in environmental samples. US Environm. Prot. Agency EPA/600/R-94/111

US Environmental Protection Agency (USEPA) 1993. Method 300.0, Determination of inorganic anions by ion chromatography. In: Methods for the determination of inorganic substances in environmental samples. US Environm. Prot. Agency EPA/600/R-93/100

Weight, W.D., 2004. Manual of Applied Field Hydrogeology. McGraw, New York, p. 192, 231-232.

Werner, E., Donovan, J.J., and Barker, E., 2008. Alkaline injection of concentrated sodium hydroxide solution into an acidic surface mine spoil aquifer. Mine Water Environ, v. 27, p. 109-121.

Whittington, B.I., 1996. The chemistry of $\mathrm{CaO}$ and $\mathrm{Ca}(\mathrm{OH})_{2}$ relating to the Bayer process. Hydrometallurgy, v. 43, p. 13-35.

Ziemkiewicz, P.F., Skousen, J.G., and Simmons, J., 2003. Long-term performance of passive acid mine drainage treatment systems. Mine Water and the Environment, v. 22 , p. $118-129$. 


\section{Appendix A: Chemistry Results}

Well Chemistry

\begin{tabular}{|c|c|c|c|c|c|c|c|c|}
\hline Well ID & $\mathrm{pH}$ & $\begin{array}{c}\text { Alkalinity } \\
\text { (meq/l) }\end{array}$ & $\begin{array}{l}\mathrm{Ca} 2+ \\
(\mathrm{mg} / \mathrm{l})\end{array}$ & $\begin{array}{l}\mathrm{Mg} 2+ \\
(\mathrm{mg} / \mathrm{l})\end{array}$ & $\begin{array}{l}\text { SO42+ } \\
(\mathrm{mg} / \mathrm{l})\end{array}$ & $\begin{array}{c}\text { Fe Total } \\
\text { (mg/l) }\end{array}$ & $\begin{array}{c}\mathrm{Al3}+ \\
(\mathrm{mg} / \mathrm{l})\end{array}$ & $\begin{array}{c}\text { Mn Total } \\
(\mathrm{mg} / \mathrm{l})\end{array}$ \\
\hline X-03 93 & 3.53 & 0.00 & 210.00 & 119.00 & 1307.00 & 31.00 & 24.00 & 22.00 \\
\hline X-04 93 & 5.64 & 1.10 & 243.00 & 189.00 & 1372.00 & 15.00 & 1.00 & 18.00 \\
\hline X-05 93 & 3.52 & 0.00 & 288.00 & 202.00 & 1684.00 & 14.00 & 34.00 & 19.00 \\
\hline X-07 93 & 4.24 & 0.00 & 58.00 & 27.00 & 369.00 & 6.00 & 13.00 & 9.00 \\
\hline X-08 93 & 3.89 & 0.00 & 206.00 & 195.00 & 1757.00 & 98.00 & 62.00 & 58.00 \\
\hline X-09 93 & 4.34 & 0.00 & 150.00 & 121.00 & 944.00 & 2.00 & 25.00 & 12.00 \\
\hline X-1193 & 3.04 & 0.00 & 167.00 & 117.00 & 1546.00 & 14.00 & 96.00 & 18.00 \\
\hline X-1293 & 5.50 & 0.32 & 147.00 & 114.00 & 915.00 & 7.00 & 0.00 & 4.00 \\
\hline X-13 93 & 3.75 & 0.00 & 184.00 & 176.00 & 1920.00 & 94.00 & 80.00 & 35.00 \\
\hline X-14 93 & 3.88 & 0.00 & 177.00 & 114.00 & 1182.00 & 28.00 & 15.00 & 34.00 \\
\hline X-15 93 & 5.78 & 1.04 & 62.00 & 28.00 & 311.00 & 55.00 & 0.00 & 7.00 \\
\hline X-16 93 & 4.20 & 0.00 & 120.00 & 100.00 & 894.00 & 56.00 & 25.00 & 21.00 \\
\hline X-17 93 & 3.57 & 0.00 & 91.00 & 61.00 & 689.00 & 39.00 & 22.00 & 14.00 \\
\hline X-18 93 & 4.93 & 0.12 & 64.00 & 38.00 & 366.00 & 39.00 & 0.00 & 5.00 \\
\hline X-19 93 & 3.95 & 0.00 & 84.00 & 42.00 & 619.00 & 2.00 & 33.00 & 11.00 \\
\hline X-20 93 & 4.48 & 0.00 & 36.00 & 10.00 & 165.00 & 2.00 & 6.00 & 5.00 \\
\hline$X-2193$ & 4.13 & 0.00 & 210.00 & 176.00 & 1588.00 & 26.00 & 28.00 & 23.00 \\
\hline X-22 93 & 3.75 & 0.00 & 269.00 & 261.00 & 2223.00 & 11.00 & 105.00 & 39.00 \\
\hline$X-2393$ & 3.65 & 0.00 & 147.00 & 161.00 & 1710.00 & 93.00 & 77.00 & 28.00 \\
\hline X-24 93 & 6.83 & 2.38 & 155.00 & 157.00 & 856.00 & 1.00 & 0.00 & 2.00 \\
\hline X-26 93 & 3.15 & 0.00 & 141.00 & 88.00 & 1030.00 & 7.00 & 51.00 & 23.00 \\
\hline X-27 93 & 4.23 & 0.00 & 207.00 & 186.00 & 1677.00 & 111.00 & 13.00 & 22.00 \\
\hline X-03 94 & 3.46 & 0.00 & 196.70 & 131.70 & 1040.00 & 42.90 & 10.60 & 17.70 \\
\hline X-04 94 & 5.48 & 2.11 & 239.20 & 161.30 & 1030.00 & 9.84 & 0.50 & 12.40 \\
\hline X-07 94 & 3.71 & 0.00 & 203.50 & 173.30 & 1312.00 & 50.14 & 84.90 & 45.90 \\
\hline X-08 94 & 4.38 & 0.00 & 93.00 & 71.40 & 520.00 & 82.40 & 3.58 & 9.98 \\
\hline X-0994 & 3.70 & 0.00 & 138.00 & 110.00 & 720.00 & 16.90 & 21.80 & 11.80 \\
\hline X-1194 & 3.08 & 0.00 & 212.00 & 195.00 & 1604.00 & 46.70 & 97.50 & 25.90 \\
\hline$X-1294$ & 4.18 & 0.00 & 156.00 & 134.00 & 1030.00 & 43.00 & 25.70 & 21.00 \\
\hline X-13 94 & 3.41 & 0.00 & 208.60 & 199.10 & 1632.00 & 107.41 & 91.00 & 40.00 \\
\hline$X-1494$ & 3.67 & 0.00 & 150.10 & 75.50 & 890.00 & 11.58 & 11.20 & 24.30 \\
\hline$X-1594$ & 5.52 & 1.18 & 81.20 & 36.20 & 328.00 & 55.30 & 0.05 & 6.45 \\
\hline
\end{tabular}


Well Chemistry Continued

\begin{tabular}{|c|c|c|c|c|c|c|c|c|}
\hline Well ID & $\mathrm{pH}$ & $\begin{array}{c}\text { Alkalinity } \\
\text { (meq/l) }\end{array}$ & $\begin{array}{l}\mathrm{Ca} 2+ \\
(\mathrm{mg} / \mathrm{l})\end{array}$ & $\begin{array}{l}\mathrm{Mg} 2+ \\
(\mathrm{mg} / \mathrm{l})\end{array}$ & $\begin{array}{l}\mathrm{SO} 42+ \\
(\mathrm{mg} / \mathrm{l})\end{array}$ & $\begin{array}{c}\text { Fe Total } \\
(\mathrm{mg} / \mathrm{l})\end{array}$ & $\begin{array}{c}\mathrm{Al3}+ \\
(\mathrm{mg} / \mathrm{l})\end{array}$ & $\begin{array}{c}\text { Mn Total } \\
(\mathrm{mg} / \mathrm{l})\end{array}$ \\
\hline X-1694 & 3.86 & 0.00 & 117.00 & 85.70 & 708.00 & 49.40 & 19.80 & 19.50 \\
\hline X-1794 & 2.56 & 0.00 & 96.90 & 67.70 & 448.00 & 46.40 & 19.90 & 12.80 \\
\hline X-19 94 & 3.25 & 0.00 & 79.10 & 48.70 & 580.00 & 48.00 & 26.20 & 12.20 \\
\hline$X-2094$ & 3.26 & 0.00 & 123.00 & 78.30 & 1046.00 & 19.26 & 42.30 & 24.90 \\
\hline$X-2194$ & 4.38 & 0.00 & 184.80 & 136.20 & 692.00 & 7.87 & 13.60 & 12.40 \\
\hline$X-2294$ & 3.14 & 0.00 & 273.00 & 227.80 & 2000.00 & 43.81 & 91.20 & 35.20 \\
\hline$X-2394$ & 3.22 & 0.00 & 160.80 & 162.20 & 1536.00 & 84.15 & 71.10 & 25.50 \\
\hline X-24 94 & 6.25 & 2.83 & 168.30 & 123.10 & 708.00 & 4.05 & 0.05 & 1.05 \\
\hline$X-2794$ & 3.68 & 0.00 & 224.50 & 196.90 & 1872.00 & 172.70 & 24.20 & 27.00 \\
\hline$X-4194$ & 2.90 & 0.00 & 204.50 & 146.40 & 890.00 & 6.74 & 75.20 & 24.70 \\
\hline$X-4294$ & 3.40 & 0.00 & 93.60 & 83.70 & 640.00 & 48.00 & 30.40 & 12.20 \\
\hline$X-3194$ & 5.16 & 0.01 & 105.00 & 48.90 & 352.00 & 105.00 & 0.49 & 17.10 \\
\hline X-45 94 & 3.63 & 0.00 & 94.12 & 58.50 & 556.00 & 77.63 & 49.10 & 28.50 \\
\hline X-46 94 & 3.90 & 0.00 & 204.30 & 161.40 & 1200.00 & 206.70 & 51.60 & 40.90 \\
\hline X-3 99 & 3.68 & 0.00 & 127.30 & 57.45 & 687.50 & 12.56 & 14.18 & 8.96 \\
\hline$X-499$ & 5.75 & 1.42 & 213.70 & 138.40 & 989.75 & 7.49 & 4.14 & 6.40 \\
\hline X-7 99 & 3.57 & 0.00 & 52.71 & 29.55 & 332.18 & 0.51 & 20.87 & 5.96 \\
\hline X-8 99 & 3.82 & 0.00 & 162.10 & 138.60 & 1246.05 & 76.04 & 87.41 & 37.41 \\
\hline X-9 99 & 6.36 & 2.88 & 66.46 & 19.49 & 191.39 & 0.12 & 1.79 & 0.35 \\
\hline$X-1599$ & 6.11 & 1.08 & 34.56 & 7.86 & 75.22 & 11.64 & 1.05 & 1.66 \\
\hline X-16 99 & 3.94 & 0.00 & 112.90 & 82.39 & 883.07 & 50.99 & 22.11 & 16.56 \\
\hline X-17 99 & 3.71 & 0.00 & 88.51 & 63.51 & 709.04 & 36.52 & 24.77 & 10.64 \\
\hline X-1899 & 4.45 & 0.54 & 63.98 & 41.19 & 297.72 & 9.69 & 2.30 & 3.95 \\
\hline X-19 99 & 4.08 & 0.00 & 56.32 & 32.70 & 364.32 & 1.64 & 20.53 & 6.54 \\
\hline X-20 99 & 3.26 & 0.00 & 94.10 & 63.16 & 546.00 & 9.47 & 33.70 & 15.40 \\
\hline X-2199 & 5.20 & 0.00 & 159.10 & 103.70 & 816.30 & 5.66 & 4.99 & 7.22 \\
\hline$X-2399$ & 3.00 & 0.00 & 115.00 & 114.30 & 959.46 & 59.39 & 66.87 & 17.92 \\
\hline$X-2799$ & 4.78 & 0.04 & 169.90 & 121.40 & 876.53 & 7.60 & 17.28 & 12.85 \\
\hline X-42 99 & 3.48 & 0.00 & 48.62 & 36.35 & 442.87 & 15.64 & 31.69 & 9.27 \\
\hline X-44 99 & 6.08 & 1.86 & 54.29 & 17.26 & 135.70 & 55.72 & 1.89 & 9.86 \\
\hline X-46 99 & 3.73 & 0.00 & 134.80 & 95.89 & 896.70 & 52.59 & 28.25 & 22.58 \\
\hline X-03 10 & 4.24 & 0.00 & 29.30 & 17.10 & 253.00 & 0.19 & 4.19 & 0.00 \\
\hline X-04 10 & 5.80 & 1.78 & 39.50 & 76.80 & 722.00 & 10.80 & 0.05 & 0.00 \\
\hline$X-0510$ & 3.41 & 0.00 & 35.00 & 41.70 & 572.00 & 0.87 & 31.30 & 0.00 \\
\hline$X-0710$ & 3.94 & 0.00 & 23.80 & 15.80 & 302.00 & 0.07 & 14.80 & 0.00 \\
\hline
\end{tabular}


Well Chemistry Continued

\begin{tabular}{|c|c|c|c|c|c|c|c|c|}
\hline Well ID & $\mathrm{pH}$ & $\begin{array}{l}\text { Alkalinity } \\
\text { (meq/l) }\end{array}$ & $\begin{array}{l}\mathrm{Ca} 2+ \\
(\mathrm{mg} / \mathrm{l})\end{array}$ & $\begin{array}{l}\mathrm{Mg} 2+ \\
(\mathrm{mg} / \mathrm{l})\end{array}$ & $\begin{array}{l}\mathrm{SO} 42+ \\
(\mathrm{mg} / \mathrm{l})\end{array}$ & $\begin{array}{c}\text { Fe Total } \\
\text { (mg/l) }\end{array}$ & $\begin{array}{l}\mathrm{Al3+} \\
(\mathrm{mg} / \mathrm{l})\end{array}$ & $\begin{array}{c}\text { Mn Total } \\
\text { (mg/l) }\end{array}$ \\
\hline X-08 10 & 3.70 & 0.00 & 35.90 & 78.40 & 1052.00 & 35.80 & 53.30 & 0.00 \\
\hline$X-1110$ & 3.11 & 0.00 & 36.90 & 63.20 & 842.00 & 4.12 & 38.80 & 0.00 \\
\hline$X-1310$ & 3.49 & 0.00 & 40.80 & 123.00 & 1250.00 & 37.90 & 59.30 & 0.00 \\
\hline$X-1410$ & 2.82 & 0.00 & 32.70 & 51.10 & 474.00 & 12.00 & 2.39 & 0.00 \\
\hline$X-1510$ & 6.71 & 2.05 & 35.10 & 39.90 & 475.00 & 42.50 & 0.05 & 0.00 \\
\hline$X-1610$ & 6.12 & 0.20 & 34.80 & 38.20 & 382.00 & 24.10 & 0.44 & 0.00 \\
\hline$X-1710$ & 6.11 & 0.35 & 39.00 & 31.00 & 412.00 & 10.30 & 0.22 & 0.00 \\
\hline$X-1810$ & 6.45 & 1.23 & 23.00 & 10.50 & 10.00 & 3.71 & 0.09 & 0.00 \\
\hline$X-1910$ & 4.05 & 0.00 & 26.50 & 19.90 & 292.00 & 1.58 & 9.61 & 0.00 \\
\hline$X-2110$ & 6.99 & 3.63 & 40.00 & 73.90 & 484.00 & 0.88 & 0.05 & 0.00 \\
\hline$X-2210$ & 4.18 & 0.00 & 41.50 & 80.70 & 782.00 & 12.90 & 15.40 & 0.00 \\
\hline$X-2310$ & 4.37 & 0.00 & 18.90 & 18.00 & 182.00 & 7.82 & 6.62 & 0.00 \\
\hline$X-4010$ & 6.45 & 1.80 & 24.50 & 3.46 & 54.00 & 0.05 & 0.05 & 0.00 \\
\hline$X-4110$ & 3.00 & 0.00 & 42.00 & 87.10 & 101.00 & 22.90 & 50.20 & 0.00 \\
\hline$X-4210$ & 6.17 & 1.48 & 39.90 & 16.90 & 296.00 & 0.05 & 0.11 & 0.00 \\
\hline$X-4310$ & 3.83 & 0.00 & 31.50 & 32.20 & 39.00 & 0.63 & 2.39 & 0.00 \\
\hline$X-4410$ & 6.20 & 4.00 & 19.20 & 8.58 & 46.00 & 15.30 & 0.05 & 0.00 \\
\hline$X-4810$ & 7.15 & 2.78 & 30.80 & 10.50 & 74.00 & 0.05 & 0.05 & 0.00 \\
\hline$X-5210$ & 4.52 & 0.00 & 48.50 & 123.00 & 1360.00 & 26.40 & 19.20 & 0.00 \\
\hline$X-5310$ & 3.32 & 0.00 & 41.10 & 82.40 & 908.00 & 14.10 & 13.10 & 0.00 \\
\hline$X-5510$ & 4.36 & 0.00 & 31.00 & 25.20 & 351.00 & 8.06 & 9.43 & 0.00 \\
\hline$X-5810$ & 6.06 & 1.50 & 39.90 & 74.40 & 600.00 & 4.76 & 0.11 & 0.00 \\
\hline X-5910 & 4.10 & 0.00 & 41.10 & 70.60 & 9.40 & 2.40 & 35.20 & 0.00 \\
\hline$X-6010$ & 6.20 & 0.39 & 32.50 & 31.80 & 328.00 & 3.93 & 0.05 & 0.00 \\
\hline$x-712$ & 5.51 & 1.02 & 168.00 & 81.20 & 924.00 & 1.08 & 1.27 & 15.90 \\
\hline$x-812$ & 3.69 & 0.00 & 100.00 & 75.40 & 996.00 & 34.30 & 40.70 & 17.10 \\
\hline X-9 12 & 11.43 & 7.06 & 170.00 & 0.32 & 97.00 & 0.08 & 6.44 & 0.00 \\
\hline$X-1212$ & 6.96 & 2.61 & 65.30 & 84.50 & 600.00 & 0.02 & 0.03 & 0.02 \\
\hline X-19 12 & 3.95 & 0.00 & 57.70 & 22.90 & 336.00 & 10.20 & 6.48 & 4.59 \\
\hline$X-2112$ & 6.38 & 4.25 & 127.00 & 76.10 & 481.00 & 0.01 & 0.01 & 0.29 \\
\hline$X-2212$ & 3.63 & 0.00 & 164.00 & 104.00 & 1083.00 & 14.30 & 20.50 & 12.50 \\
\hline$X-2312$ & 3.54 & 0.00 & 81.00 & 70.40 & 832.00 & 32.50 & 33.40 & 12.50 \\
\hline$X-2612$ & 6.16 & 1.51 & 262.00 & 22.10 & 826.00 & 4.94 & 0.88 & 4.23 \\
\hline$X-2712$ & 6.36 & 1.23 & 35.10 & 8.94 & 140.00 & 0.11 & 0.08 & 0.37 \\
\hline X-41 12 & 2.81 & 0.00 & 139.00 & 87.80 & 1137.00 & 6.33 & 48.80 & 10.70 \\
\hline
\end{tabular}


$\underline{\text { Well Chemistry Continued }}$

\begin{tabular}{|l|r|r|r|r|r|r|r|r|}
\hline Well ID & \multicolumn{1}{|c|}{$\mathrm{pH}$} & $\begin{array}{c}\text { Alkalinity } \\
(\mathrm{meq} / \mathrm{l})\end{array}$ & \multicolumn{1}{c|}{$\begin{array}{c}\mathrm{Ca}+ \\
(\mathrm{mg} / \mathrm{l})\end{array}$} & $\begin{array}{c}\mathrm{Mg} 2+ \\
(\mathrm{mg} / \mathrm{l})\end{array}$ & $\begin{array}{c}\text { SO42+ } \\
(\mathrm{mg} / \mathrm{l})\end{array}$ & $\begin{array}{c}\text { Fe Total } \\
(\mathrm{mg} / \mathrm{l})\end{array}$ & $\begin{array}{c}\text { Al3+ } \\
(\mathrm{mg} / \mathrm{l})\end{array}$ & $\begin{array}{c}\text { Mn Total } \\
(\mathrm{mg} / \mathrm{l})\end{array}$ \\
\hline X-45 12 & 2.29 & 0.00 & 195.00 & 81.80 & 1150.00 & 79.80 & 8.38 & 23.80 \\
\hline X-52 12 & 5.38 & 1.08 & 315.00 & 114.00 & 1534.00 & 20.30 & 2.76 & 17.20 \\
\hline X-54 12 & 6.63 & 2.61 & 59.80 & 8.45 & 107.00 & 0.02 & 0.03 & 0.04 \\
\hline X-59 12 & 4.14 & 0.00 & 130.00 & 89.70 & 960.00 & 6.31 & 18.40 & 12.90 \\
\hline X-60 12 & 6.08 & 1.45 & 85.90 & 37.50 & 366.00 & 0.89 & 0.45 & 6.53 \\
\hline
\end{tabular}




\section{Appendix B: R Script}

\section{$\underline{\mathrm{R} \text { Script for Cluster Analysis and Dendrogram }}$}

AllChem = read.delim('FILE NAME ',stringsAsFactors=FALSE) \# reads the file AllChem.use $=$ AllChem $[c(2,3,4,5,6,7,8,9)] \quad$ \#strips the text from the input file means $=$ apply(AllChem.use,2,mean) \#vector of means sds= apply(AllChem.use,2,sd) \#vector of std deviations AllChemScaled $=$ scale (AllChem.use,center=means,scale=sds) \#normalizes to z scores AllChem.dist $=\operatorname{dist}($ AllChemScaled $) \quad$ \#euclidean similarity AllChem.hclust $=$ hclust(AllChem.dist, "ward") \#clusters on the distance matrix plot(AllChem.hclust,labels=AllChem $\$ i d$, cex=.75, main='Well Chemistry Cluster Analysis', xlab=") \# plots the dendrogram groups. $4=$ cutree(AllChem.hclust,4) \#head counts for 4 clusters table(groups.4)

rect.hclust(AllChem.hclust, $\mathrm{k}=4$, border="red") \# draws the red boxes around each cluster

\section{$\underline{\text { R Script for Boxplots }}$}

\#Boxplots for meq/l

AllChem4=cbind(AllChem,groups.4)

$\operatorname{par}(\mathrm{mfrow}=\mathrm{c}(4,1))$

boxplot(subset(AllChem4[,2:8],AllChem4[,9]==1), horizontal=FALSE, ylim=c(0,40)) text(c(1.5),"cluster 1")

boxplot(subset(AllChem4[,2:8],AllChem4[,9]==2), horizontal=FALSE, ylim=c(0,40)) text(c(1.5),"cluster 2")

boxplot(subset(AllChem4[,2:8],AllChem4[,9]==3),horizontal=FALSE, ylim=c(0,40)) text(c(1.5),"cluster 3")

boxplot(subset(AllChem4[,2:8],AllChem3[,9]==4),horizontal=FALSE, ylim=c(0,40)) text(c(1.5),"cluster 4")

\section{$\underline{\mathrm{R} \text { Script for Star Plots }}$}

Allchem2 = read.csv(na.omit("FILENAME"))

Allchem2id = read.csv(na.omit("FILENAME"))

id <- as.vector(Allchem2id\$id)

palette $(\operatorname{gray}(\operatorname{seq}(0,1$, len $=8)))$ 
stars (Allchem2, labels $=\mathrm{id}$, len $=1$, nrow $=7$, key.loc $=\mathrm{c}(39,15)$, draw.segments $=$ +TRUE)

\section{$\underline{\mathrm{R} \text { Script for numerical Integration }}$}

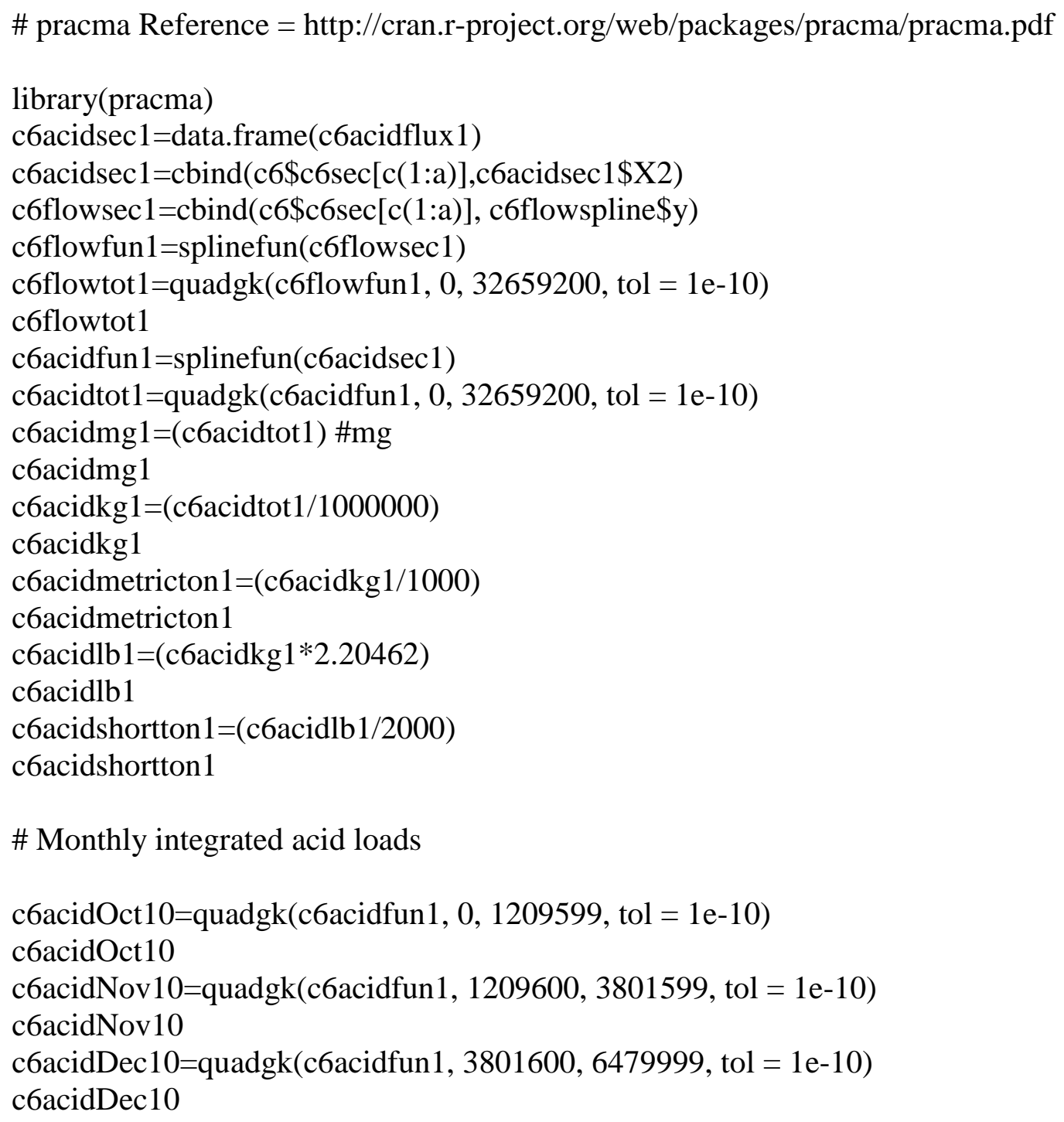

